\title{
Yerel İnternet Gazetesi Haberlerinde Balıkesir Turizmi ${ }^{1}$
}

\author{
Sultan Nazmiye KILIÇ ${ }^{2}$, Hasret ULUSOY $^{3}$ ve Cevdet AVCIKURT ${ }^{4}$ \\ $\ddot{O} z$
}

$\mathrm{Bu}$ araştırmanın amacı, Balıkesir turizminin yerel internet gazetelerinde yer alan haberlerde nasıl yer aldığının ortaya çıkarılmasını sağlamaktır. Bu amaç doğrultusunda nitel araştırma yöntemi kullanılarak doküman incelemesi yapılmıştır. Elde edilen verileri derinlemesine incelemek amacıyla temalar, kategoriler ve kodlar belirlenmiştir. Geriye dönük incelemede haberler, içerik ve sayısal yönden incelenmiştir. Basın İlan Kurumu'nun resmi web sayfasındaki Balıkesir başlığı altında yer alan yerel gazeteler taranmıştır. Ayvalık, Bandırma, Burhaniye, Edremit, Erdek, Gömeç, Gönen, Manyas, Sindırgı olmak üzere dokuz ilçede ve merkezde toplam 26 yerel internet gazetesi incelemeye tabi tutulmuş, turizm haberi içeren 19 gazete değerlendirmeye alınmıştır. Yerel gazetelerin web sayfalarında "Balıkesir" ve “Turizm” anahtar kelimeleri aratılmıştır. Veri toplama süreci, Ocak 2019-Ağustos 2019 tarihleri arasında yılın ilk sekiz ayını kapsayan süreçle sınırlandırılmıştır. Bu sınırlama ile elde edilen veriler 2019 yılı Balıkesir turizmine yönelik gelişmelere ve değişimlere 1şık tutmaktadır. Araştırma sonuçları doğrultusunda içerik yönünden özgün haberlerin yapılması, destinasyona yönelik tanıtıcı köşe yazılarının artırılması ve Balıkesir turizminin ulusal basında da yer alması gerekliliğine ilişkin öneriler sunulmuştur.

Anabtar Kelimeler: Balıkesir, Balıkesir Turizmi, Yerel İnternet Gazetesi Haberleri

\section{Balıkesir Tourism in the Local Internet Newspaper News}

\begin{abstract}
The aim of this research is to find out how Balikesir tourism takes place in the local newspaper news. For this purpose, document analysis was conducted by using qualitative research method. Themes, categories and codes were determined in order to examine the obtained data in depth. In the retrospective analysis, the news was examined in terms of content and quantitative aspects. Local newspapers under the title of Balıkesir on the official website of the Press Advertisement Agency were scanned. 26 local newspapers of nine districts that are Ayvalık, Bandırma, Burhaniye, Edremit, Erdek, Gömeç, Gönen, Manyas, Sındırgı and the center were examined, 19 newspapers containing tourism news were evaluated. "Balıkesir" and "Turizm" keywords were searched on the local newspaper web pages. The data collection process was limited to the first eight months of the year between January 2019 and August 2019. The data obtained with this restriction sheds light on the developments and changes towards Balıkesir tourism in 2019. In line with the results of the research, suggestions such as making original news in terms of content, increasing the promotional columns for the destination and the necessity of Balikesir tourism to be included in the national press were also presented.
\end{abstract}

Key Words: Balıkesir, Balıkesir Tourism, Local Internet Newspaper News

\author{
Atıf İçin / Please Cite As: \\ Kılıç, S. N., Ulusoy, H. ve Avcıkurt, C. (2021). Yerel internet gazetesi haberlerinde Balıkesir turizmi. Manas Sosyal \\ Arastirmalar Dergisi, 10(2), 1281-1299.
}

Geliş Tarihi / Received Date: 15.04.2020

Kabul Tarihi / Accepted Date: 18.01.2021

\footnotetext{
1 19-22 Eylül 2019 tarihleri arasında Balıkesir'de düzenlenen Milli Mücadele’nin 100. Yıllnda "Kuva-yı Milliye Şehri Balıkesir" Uluslararası Sempozyumu'nda sunulan sözlü bildirinin gözden geçirilmiş ve yeniden düzenlenmiş hâlidir.

2 Arş. Gör. Dr. - Balıkesir Üniversitesi Turizm Fakültesi, sultan.kilic@balikesir.edu.tr

(iD ORCID: 0000-0003-0560-0622

3 Arş. Gör. - Balıkesir Üniversitesi Turizm Fakültesi, hasretulusoy@balikesir.edu.tr

(iD ORCID: 0000-0003-1633-6804

4 Prof. Dr. - Balıkesir Üniversitesi Turizm Fakültesi, avcikurt@balikesir.edu.tr

(iD ORCID: 0000-0002-9169-9763
} 


\section{Giriş}

İnsanoğlu var olduğu zamandan beri sürekli üretme ve keşfetme uğraşı içinde doğaya egemen olma savaşı vermektedir. Bu çaba, teknolojinin gelişmesi ile birlikte insanların tüm yaşamını etkilemiştir (Kazaz, 2007, s. 220). 21. yüzyıldan itibaren bilgiye ve bilgi teknolojilerine olan önem artmış, işin altyapısını oluşturan teknolojinin hızlı gelişimi (Birsen, 2005, s. 69), kamu yararına sunulan kitlesel iletişim aracı olan internetin (Şahan ve Çınar, 2004, s. 315) gelişmesini ve büyümesini sağlamıştır (Yücedoğan, 2002, s. 143144; Halıc1, 2005, s. 155; Kazaz, 2007, s. 220).

Günümüzde internet, yaşamın hemen hemen her alanında var olan ve sürekli yaygınlaşan bir olgudur. Kullanımındaki yaygınlıkla birlikte gazetecilik alanı da etkilenmiş (Aral, 2019, s. 155), bu alanda önemli gelişmeler olmuştur (Kutlu ve Bekiroğlu, 2010, s. 255; Işı1k ve Koz, 2014, s. 28; Öztürk, 2018, s. 198). İnternet, kısa zamanda gazeteciliğe yeni bir boyut kazandırmıştır (Gürcan ve Bekiroğlu, 2007, s. 23; Korkmaz, 2009, s. 7; Yegen, 2014, s. 15; Narin, 2016, s. 119). İnternet üzerinden yayıncllık diğer yayınc1lık türleriyle kıyaslandığında çok daha düşük maliyetli olduğundan yazılı basın, görsel medya ve kendi alanlarına yönelik çalısmaların yanı sıra internet haberciliği alanına da oldukça kısa bir sürede girilmiştir (Ayvaz, 2008, s. 61; Yurdigül ve Zinderen, 2012, s. 85). Bu bağlamda internet, haber sunmak için yeni bir araç konumuna gelmiş, bilginin yalnızca yayılmasına değil; yeniden üretilmesine ve yeni biçimlerde sunulmasına ortam sağlamıştır (Çakır, 2007, s. 125). Habercilik alanında önemli bir dönüm noktası olan bu süreçte, bir taraftan gazetelerin basılı nüshaları sanal ortama aktarılmış, bir taraftan da internet haber portalları oluşturulmuştur (Özdemir ve İlhan, 2012, s. 810). İnternet haberciliğinin sağladığı imkânlar ve sahip olduğu potansiyel yerel basın açısından önem taşımaktadır. İnternet haberciliği, bir yörede/bölgede faaliyet gösteren, o yörenin/bölgenin olaylarını, gelissmelerini, sorunlarını konu edinen yerel basına katkı sağlamaktadır. Bu katkılar; internet ortamında yörenin/bölgenin sesini kentin dışına duyurabilmesi, daha çok insana ulaşma potansiyeline sahip olması ve içinde bulunduğu coğrafi sınırların dışında da yer alabilmesi şeklinde ifade edilebilmektedir (Gürcan ve Bekiroğlu, 2007, s. 23).

İletişim ve etkileşimin uluslararası düzeyde arttığı dünyada yükselen bir değer olan turizm, tüm ülkeler için vazgeçilmez bir saha olarak görülmektedir (Yllmaz ve Parlak, 2017, s. 110). Bir turistik destinasyona ilişkin bilgi edinme kaynakları arasında turizm ofisleri, seyahat rehberleri, satış görevlileri, seyahat acenteleri, broşürler, sosyal ağlar, yakınlar, arkadaşlar, gazeteler, dergiler, radyo, televizyon ve internetten elde edilen basilı veya elektronik bilgiler bulunmaktadır (Bargeman ve van der Poel, 2006, s. 709). Bu anlamda turizm, bir bölgeyi farklı boyutlardan etkilediği için yerel gazete haberlerinde üzerinde durulan konulardan biridir. Yapılan çalışmalarda da bir bölgedeki turizmin gelişiminin veya imajının anlaşılabilmesi için haber inceleme yöntemi kullanıldığı görülmektedir. Bu çalışmalarda, yerel gazeteler de kaynak olarak kullanılmıştır. Yerel gazete haberleri, şehrin aynası olduğundan imaj ve markalaşma açısından önemli role sahiptir (Ylldırım ve Karaahmet, 2013).

Balıkesir ili, doğal, kültürel ve tarihi değerleri bünyesinde barındıran, zengin bir mirasa sahip olan önemli bir turizm merkezidir (Çetiner ve Çetiner Gökyllmaz, 2006, s. 254; Gürdal, 2006, s. 229). Bu doğrultuda, bu çalışmada Balıkesir ilinde turizm hususunda kaydedilen gelişmeler, yaşanılan değişimler ve güncel olaylar ele alınmıştır. Balıkesir ilindeki internet haberciliğinin turizm farkındalığı ve basına yansıyan yüzü ile Balıkesir turizmi incelenmiştir. Çalışmada, Balıkesir ilinde gerçekleşen turizm faaliyetlerinin gazetelerde ne kadar ve nasıl yer aldığının belirlenmesi hedeflenmiştir. Buradan hareketle bu çalışmanın amacı, Balıkesir ilinde turizm hareketlerinin neler olduğu ve Balıkesir turizminin çevrimiçi ulaşılabilen yerel gazete haberlerinde nasıl yer aldığının ortaya çıkarılmasını sağlamaktır. Çalışmada yerel gazete haberleri üzerinden Balıkesir turizminin genel çerçevesi belirlenmeye çalışılmıştır. Balıkesir ilinin iç turizm hareketlerinin ilk görüldüğü yerlerden biri olma özelliği taşıdığı göz önünde bulundurulduğunda, mevcut turizm hareketlerinin nasıl olduğu ve nelerin yerel gazete haberlerinde yer aldığının tespit edilmesi önem arz etmektedir. Literatürde bu yönde bir çalışmaya rastlanmamış olup, çalışmanın turizm hareketlerinin yerel gazete haberlerine nasıl yansıdığı noktasında farkındalık oluşturacağı ve bu çerçevede çalışmanın alanyazına katkı sağlayacağı düşünülmektedir.

\section{İnternet Haberciliği}

Ulusal ölçekli gazeteler göz önünde bulundurulduğunda hemen hemen tamamının kendi internet sitelerini kurdukları ve bu internet sitelerinde habercilik yapmaya başladıkları görülmektedir (Çakır, 2007, s. 138; Yegen, 2014, s. 20). İnternet gazeteleri, televizyon ve basill günlük gazeteler gibi bireysel tüketici düzeyinde olduğu kadar toplum düzeyde de farklı işlevlere hizmet etmektedir (Reichart ve Hischier, 2001, s. 92). Basilı gazetelerden haber okuma, yerini internet gazeteleri ile birlikte bilgisayar, tablet ve telefonlar 
vasıtasıyla internet haberlerine birakmıştır (Aral, 2019, s. 155). İnternet gazetelerinde yer alan haberlere erişim hızlı ve kolay olmakta; ayrıca haberlere zaman kısıtlaması olmadan erişim sağlanmaktadır (Ayhan ve Kükrer Aydın, 2015, s. 76). Illgili alanyazında yeni medya ile gazetecilik, "gazetecilik 2.0", "elektronik gazetecilik", "internet gazeteciligi/ haberciligi", "sanal gazetecilik", "online gazetecilik/ habercilik", "sevrimiç gazetecilik", "dijital gazetecilik", "multimedya gazeteciligï", "siber gazetecilik", "network gazetecilik." gibi isimlerle anılmaktadır. Anlaşlır olması ve yaygın olarak kullanılması sebebiyle Türkçe'de genel olarak "internet gazeteciligüi/ haberciliğ " terimi tercih edilmektedir (Narin, 2016, s. 120).

Türkiye'de internet haberciliğinin geçmişi çok eski olmamasına karşın çok hızlı bir biçimde gelişim göstermektedir (Ayvaz, 2008, s. 65; Korkmaz, 2009, s. 11). Ülkemizde internet haberciliği, "1995-2000 yılları arasında internetin ortaya çıkması ve gelişmesini kapsayan dönem" ve "2000’li yıllarda başlamış olan dönem" olmak üzere iki dönemde ele alınmaktadır. Gerçek anlamda internet haberciliğinin olduğu dönem olarak adlandırilan ikinci dönem itibariyle (Gürcan, 2005, s. 41) internet haber siteleri, sürekli olarak güncellenmekte; yerli ve yabancı olmak üzere çok sayıda gazeteye internet üzerinden ulaşım sağlanmaktadır. İnternet haberciliği ile haber seçme olanağının yanı sıra hem güncel haberlere hem de arşiv haberlerine erişim olanağı tanınmaktadır (Halıcı, 2005, s. 158). Bu bağlamda, internet haberleri okurlarına haberlerini daha hızlı ve daha güncel bir şekilde ulaştırmaktadır (Ayhan ve Kükrer Aydın, 2015, s. 76). İnternet haberciliğinin olanakları ve geleneksel habercilikten farklılıkları şu şekilde aktarılmaktadır (Karaduman, 2005, s. 146-147):

- Haber hızlı bir şekilde verilmekte ve güncellenmektedir.

- Habere istenilen vakitte erişim sağlanmaktadır.

- Multimedya temelindeki dosyalar kullanilabilmektedir.

- Arşivdeki haberler ulaşabilir olmaktadır ve arzu edilen haberler depolanabilmektedir.

- İnteraktif etkileşim kurulabilmektedir, okuyucu yorumlarına yer verilebilmektedir.

- Verilen link sayesinde haberlere ilişkin konuların arka plan bilgilerine erişilebilmektedir.

- Medyada bulunmayan haberlere de ulaşılabilmektedir.

İnternet haberciliği sayesinde bireyler, haberleri günlük değil, anlık takip edebilmektedir. İstedikleri zaman haber sitelerini ziyaret edebilmekte; kısa sürede haberleri tarayabilme imkânına sahip olabilmektedir (Yücedoğan, 2002, s. 146; Korkmaz, 2009, s. 14). Hızlı ve çok sayıda haber ulaştırması nedeniyle internet haberciliği, geniş kitleleri haber sahibi yapma misyonu da üstlenmektedir (Yegen, 2014, s. 20). Ancak internet haberciliğinin olumlu yönlerinin yanı sıra olumsuz yönleri de bulunmaktadır. Medyanın günümüzde geldiği nokta göz önünde bulundurulur ise, etkisi altında kalınan veya benimsenen bazı fikir ve görüşlerin kitlelere aktarılmaya çalışılması söz konusu olabilmektedir (Bal, 2011, s. 202). Öte yandan internetin katılıma açık olması ve çift yönlü iletişim sağlaması, internet ortamının kontrol edilebilirliğini azaltmakta ve ortamı, herkesin özgürce istediğini söyleyebileceği bir platforma dönüştürmektedir (Birsen, 2005, s. 70). Böylece internet haberciliğinde okuyucu, yayının bir parçası durumuna gelmektedir (Çakır, 2007, s. 142).

\section{Yerel Gazeteler ve Balıkesir}

Bulunduğu il, ilçe, yöre/bölgede meydana gelen sosyal, ekonomik, siyasi ve kültürel olaylar ve etkinlikler yerel basının içeriğini oluşturmaktadır. Gazeteler ve dergiler, belirli bir il, ilçe, yöre/bölgeye yönelik bilgiler içeren yerel basın kavramı kapsamında değerlendirilmektedir (Yeşil, 2015, s. 202). Yerel gazeteler, bulundukları yöre/bölge ile ilgili günlük haberlere ayrıntılı olarak yer vermektedir (Öztürk, Zülkadiroğlu, İnce ve Şahin, 1999, s. 2). Oskay (2001) yerel gazetelere ilişkin "yaşadıklar büyük kentte yaymlanan gazetelerdeki haberleri okumak bu insanlara bilinmezliklerle dolu kent ortamm biliyormus duygusu kaz̧andrmakta; kentin karşısında duyduklar korkuyu az̧altmaktadır." ifadelerini kullanmaktadır (Akt: Erdoğan, 2006, s. 52). Gazeteler, toplumsal ve kültürel işlevleri yerel anlamda gerçekleştirme bakımından önemli kitle iletişim araçları arasında yer almaktadır (Şeker, 2005, s. 101).

Dünya üzerinde var olan olay/olguların yerel bölge açısından değerlendirilmesi, hazırlık (sayfa tasarımı, içerik vb.) aşamasında yerel farklılıkların göz önünde bulundurulması, bir başka ifadeyle dünyaya yerel pencereden bakılması ve yerel halkın ihtiyaçlarının (haber, bilgi vb.) karşılanması yerel gazetelerin amaçları arasında yer almaktadır (Güllü, Kacur ve Tanyeri, 2009, s. 272). Bununla birlikte yerel gazeteler, kendi kentlerinden, yörelerinden/bölgelerinden uzak mesafelerde yaşayan bireylere ulaşarak, onlara haber eriştirmek noktasında ulaştırma işlevi görebilmektedir (Gürcan ve Bekiroğlu, 2007, s. 24). Yerel gazeteler, 
bölgesel gelişim sağlaması, yerel halkın, şehrin ve toplumun gelişiminden haberdar olması, bireysel gelişimi pekiştirmesi bakımından önem arz etmektedir. Yerel gazetelerde bulunan eğitim, sağlık gibi alanlara ilişkin haberler, bireylerin kişisel gelişimine katk1 sunarak bireysel fayda sağlarken, sosyo-kültürel ve çevresel alanlara ilişkin haberler, toplumsal fayda sağlamaktadır (Çuhadar ve Ünal, 2017, s. 416-417). Okurlara aitlik duygusu kazandırma ve ait olma bilinci aşılama konusunda yerel gazeteler önemli görevler üstlenmektedir (Erdoğan, 2006, s. 52). Günümüzde gazetelerden, bulunduklar1 yörede/bölgede var olan sorunlara eğilmeleri, çözüm odaklı bir platform olmaları, okurlarının ufkunu genişletmeleri, bilinç düzeyini artırmaları ve bu sayede yerel gelişimi hızlandırmaları beklenmektedir (Şeker, 2005, s. 101).

Osmanl döneminde gazetelerden "toplumu demokratiklestitirme, çă̆daşlaştrma, ideoloji üretme ve yayma, eğitim ve kültür ibtiyacın karşılama" gibi büyük boyutlu görevler beklenmiş, Osmanll gazeteciliğinde vilayet gazetelerinin doğuşu bu şekilde gerçekleşmiştir (Kocabaşoğlu ve Birinci, 1995, s. 101). Balıkesir'de ilk gazete olma özelliğini taşıyan Karesi Gazetesi, 1886 yılında basılmış ve yayımlanmıştır. Gazete, halkın eğitimine hizmet etme işlevini yerine getirmekle birlikte, içeriğinde sanat, ziraat, ticaret konularında halkın bilinç kazanmasına yardımcı olan kanun, nizamname, makaleler ve günlük olaylara yer vermiştir (İskender, 2005, s. 85-88). Milli Mücadele'nin kıvılcımlarının ortaya çıkmaya başladığı Ses Gazetesi, Balıkesir'de 17 Ekim 1918 ile 13 Mart 1919 tarihleri arasında Hasan Basri (Çantay) tarafindan haftalık bir gazete olarak 22 sayı yayınlanmıştır. Gazetenin amaçları arasında halkı bilgilendirmek, ülke ve yöre/bölge hakkında halkı aydınlatmak bulunmaktadır (Yazıc1, 1993, s. 435-441). Kuva-yı Milliyenin sesi olarak nitelendirilen İzmir'e Doğru Gazetesi ise 16 Kasım 1919-27 Haziran 1920 tarihleri arasında yayınlanmıştır (Keleşyllmaz, 1997, s. 249). Polat (2002, s. 14)'a göre Balıkesir'deki süreli yayınlar arasında İrşat (1920-1922), Karesi (1) (19221924), Karesi (2) (1923), Karesi (3) (1925-1926), Türk Dili (1927-1940) ve Zafer-i Millî (1928) bulunmaktadır. 1980’li yıllar itibariyle Balıkesir'de Hizmet Gazetesi (Ocak 1988-1991 Eylül), Demokrat Gazetesi (Temmuz 1989-2006 Aralk), Ekspres Gazetesi (Ocak 1988-2006 Aralik), Haberci Gazetesi (Ekim 1996-2006 Aralık), Marmara Gazetesi (Temmuz 1996-2006 Aralık), Olay Gazetesi (Ocak 19952006 Aralık), Politika Gazetesi (Ocak 1988- 2006 Aralık), Son Nokta Gazetesi (Aralık 1999- 2000 Aralık), Star Gazetesi (Mayıs 1996- 2001 Aralık), Yeni Balıkesir Gazetesi (Ocak 1993- 2006 Aralık), Yeni Haber Gazetesi (Ocak 1988- 2006 Aralık) faaliyet göstermiştir (Balıkesir Büyükşehir Belediyesi Kent Arşivi, 2019).

\section{Balıkesir Turizmi}

Balıkesir, doğal, kültürel ve tarihi değerleri bünyesinde barındıran, zengin bir mirası bulunan önemli bir turizm merkezidir (Çetiner ve Çetiner Gökyılmaz, 2006, s. 254; Gürdal, 2006, s. 229). Balıkesir ilinin Ege ve Marmara olmak üzere iki farklı denize kıyısının olması, coğrafi konumu, iklimi ve doğasının kıyı turizmine elverişli olması, Ayvalık, Burhaniye, Gömeç, Altınova, Edremit, Akçay, Altınoluk, Erdek ve Marmara ilçelerinde plajlarını olması dikkat çeken yönleri arasındadır (Ulusoy Yıldırım, Köroğlu, Avcıkurt ve Köroğlu, 2018, s. 220).

Kültür turlarının gerçekleştirildiği alanlar arasında yer alan Kazdağları ile özdeşleşmiş olan Türkmen ve Yörük kültürleri ve bu kültürlere ilişsin efsaneler dikkat çekmektedir. Kazdağlarında bulunan "Sarıkır. Türbesi, Baba Tepe ve Gargaros (Karatass) Tepe; Ayı Deresindeki Elif Kaçan; Hasanboğuldu" ve etnografya galerileri en çok ziyaret edilen alanlar olarak tanınmaktadır (Anı, 2009, s. 425). Kültür turları kapsamında müzeler, geçmiş ve gelecek arasında bağ kurarak yörenin/bölgenin anlaşılmasını, yöre/bölge kültürünün tanınmasını sağlamaktadır. "Ballkesir Kuva-yı Milliye Müzesi, Tabtakuşlar Etnografja Müzesi, Sıdıka Erke Etnografja Mü̈esi, Banderma Arkeoloji Müzesi, Bigadic Müze ve Kültür Evi, Gönen Mozaik Müzesi, Saraylar Köyü Açlk Hava Mǚresi, Sevim ve Necdet Kent Kitapluğı, Taksiyarbis Kilisesi Ant Müze, Bahkesir Gazeteciler Cemiyeti Basin Müzesi, Bahkesir Ulusal Fotoğraf Müzesı”” ziyaret edilen müzelerdir (Balıkesir İl Kültür ve Turizm Müdürlüğü, 2019b). Ayrıca "Burhaniye Kwva-yn Milliye Kültür Müzessi, Kǚ̆ükeköy Kent Müzesi Arşivi ve Ayışı̆̆g Manastır (Aya Dimitri ta Selina) Müzesi” de Balıkesir ilinde hizmet veren özel müzelerdir (Gül ve Gül, 2017, s. 57). Müzelerin yanı sıra Daskyleion Antik Kenti, Antandros Antik Kenti, Kyzikos Antik Kenti ve Adramytteion Antik Kenti de ildeki önemli antik kentlerdir (Balıkesir Kent Portal1, 2019). Ayvalık ve çevresi kültür turizmi ve dalış turizmi, Edremit Kazdağları Milli Parkı flora ve fauna, endemik bitki türleri, su kaynakları, Kapıdağ Yarımadası ve Alaçam Dağları ekoturizm, Bandırma Kuş Cenneti Milli Parkı ornitoloji, ilk turizm hareketlerinin var olduğu "Erdek ve Aksay, Altmoluk, Ayvallk-Sarmmsakl, Alibey Adası, Altmova, BurbaniyeÖren, Gömę- Artur, Marmara, Saraylar Köyü ve Avşa Adaları" deniz turizmi, Gönen, Edremit Güre, Sindırg1, Bigadiç, Balya termal turizm ile ön plana çıkmaktadır (Balıkesir İl Kültür ve Turizm Müdürlügü, 2019a). 
Kırsal turizm potansiyeli açısından da oldukça zengin olan Balıkesir, sahip olduğu coğrafya, doğal ve kültürel kaynaklar ile güçlü bir profil çizmektedir (Polat, Özdemir ve Özdemir, 2014, s. 143). "Ekoturizm, kus gözlemciliği, endemik bitki gözlemciliüg, mağara turizmi, av turizmi, yayla turizmi, kamp ve karavan turizmi, trekking ve dăg turizmi" Balıkesir ilinde kırsal turizm faaliyetlerine örnek olarak gösterilebilmektedir (Özdemir Yılmaz ve Kafa Gürol, 2012, s. 28). Balıkesir'de kırsal alanlarda gerçekleştirilebilecek alternatif turizm türlerinden birinin de astro-turizm olduğu belirlenmiştir. Astro-turizm kapsamında Balıkesir ilinde yer alan "Sındırg1-Düvertepe, Bigadiç-Meyvalı, Kepsut-Yeşildağ/Serçeören" ilgili koşullara uyum göstermiştir. Belirtilen bölgelerin konaklama ve ulaşım gibi turizm arzına sahip olması, astro-turizm faaliyetlerini olanaklı kılmaktadır (Karaca, Ertürk, Köroğlu ve Özdemir Yılmaz, 2018, s. 7). Balıkesir ilinin mağara turizmi potansiyeli kapsamında ise Kepsut-Ulupınar, Gönen-Dereköy, Havran-İnboğazı, ve Bigadiç-Meyvalı mağaraları olmak üzere dört mağaradan söz edilebilmektedir. Bu mağaralar insan girişine kısmen açık, fakat turizme henüz açılmamış mağaralar olan ikincil mağaralar grubunda değerlendirilebilmektedir (Soykan, Efe, Sönmez ve Cürebal, 2008, s. 396-399). İlban, Köroğlu ve Bozok (2008, s. 124) tarafindan yapılan çalışma, termal turizm kapsamında ele alınmış ve çalışmada Gönen’i ziyaret eden turistlerin Gönen’e ilişkin akıllarına ilk önce kaplıcaların geldiği belirlenmiştir.

Burhaniye ilçesinde düzenlenen "Burhaniye Ören Turizm Kültür ve Sanat Festivali", "Uluslararas1 Burhaniye Zeytin ve Zeytinyağı Festivali”, "Pelitköy Geleneksel Zeytin ve Deve Güreşleri Festivali”, “Taylieli köyü Kültür, Sanat ve Tiyatro Şenliği”, ilçenin sosyo-kültürel yaşamına destek vermektedir. "Dağ, doğa, mağara, botanik, yayla, çiftlik, akarsu, tormanıs, trekking, kamp-karavan, bisiklet, foto safari ve yaban hayatı gözleme” gibi ekoturizm türlerini de bünyesinde barındıran Burhaniye ilçesi, hem bu turizm türünün bölgede devam ettirilmesine hem de yerel halkın turizm faaliyetlerine katılmasina katkıda bulunmaktadır (Çelik Uğuz, 2011, s. 339-344). "Uluslararası Bandırma Kuş Cenneti Kültür ve Turizm Festivali” 1987 yılından bu yana düzenlenmektedir. Bandırma Kuş Cenneti ve Kuş Gölü’ne ilişkin sorunları ve bu sorunlara yönelik çözüm önerilerini belirlemek amacıyla düzenlenen festivalde, bilimsel toplantılar, eğlence programları ve kültür-sanat etkinlikleri gerçekleştirilmektedir (Balıkesir Valiliği, 2017, s. 37). Zengin bir flora ve faunaya sahip olan kuş cenneti, endemik bitki gözlemciliği için de önemli noktalardan biridir (Doğa Koruma ve Milli Parklar Genel Müdürlüğ̈̈, 2012).

Türk Patent ve Marka Kurumu (2019) Coğrafi İşaret ve Geleneksel Ürün Adı İstatistikleri’ne göre Balıkesir ilinin coğrafi işaretleri arasında "Ayvalık Zeytinyağı, Balıkesir Höşmerim Tatlısı, Balıkesir Kuzu Eti, Edremit Körfezi Yeşil Çizik Zeytin, Edremit Zeytinyağı, Gönen İ̆ne Oyas1, Kapıdağ Mor Soğan1, Marmara Adas1 Mermeri/Marmara Mermeri/Marmara Beyaz1, Susurluk Ayranı, Susurluk Tostu, Yağcıbedir El Halısı" yer almaktadır. Coğrafi işaretlerin ağırlıklı olarak gastronomi ve kültürel değerler olduğu görülmektedir. Bu coğrafi işaretler ile turizmi ilişkilendiren Polat (2017, s. 27), Balıkesir ilinde faaliyet gösteren turizm işletmeleri tarafından gastronomi alanındaki coğrafi işaretli ürünlerin kullanılmasının ve coğrafi işaretli ürünlere ilişkin bilginin turistlerle paylaşılmasının, yerel tatları deneyimleme firsatını yakalamış olan turistlerin yöreyi/bölgeyi tekrar ziyaret etme davranışına olumlu yönde katk1 sağlayacağını belirtmiştir.

Turizm alanında haber incelemesi yöntemini kullanarak farklı konuları ve farklı şehirleri değerlendiren çalışmalar hazırlanmıştır. İlgili alanyazın incelediğinde, turist ölümleri (Sezen Doğancıll, 2019; Kervankıran, Çuhadar ve Ongun, 2020), kadın turistlerin medyada yer alması (Tuncel, 2011), turizmin zararı (Güzel, 2012), yavaş şehir olma süreci (Ylldırım ve Karaahmet, 2013), imaj (Bayram, 2016), sağlık turizmi (Bayram, Erkol Bayram ve Ak, 2018), Türk Mutfağı (Yılmaz ve Çakı1, 2019) konuları çalışma alanı bulmuştur. Ayrıca, Türkiye ulusal turizm haberlerinin incelenmesi (Kervankıran ve Aktürk, 2016; Şimşek ve Hassan, 2018), Trabzon turizm farkındalı̆g1 (Yılmaz ve Parlak, 2017) ve Eskişehir turistik çekiciliklerinin (Aydın ve Aydın, 2020) ele alınmış olmasından hareketle, Balıkesir ilinin iç turizm hareketlerinin ilk görüldüğü yerlerden biri olma özelliği taşıdığı göz önünde bulundurularak, mevcut turizm hareketlerinin nasıl olduğu ve nelerin yerel gazete haberlerinde yer aldığının tespit edilmesi önem arz etmektedir. Çalışmanın bu açıdan literatüre katkı sağlayacağı düşünülmektedir.

\section{Yöntem}

Gazete haberleri bir turizm destinasyonunun mevcut durumunun anlaşılması ve destinasyon imajının yansıtılması açısından veri kaynağı olarak kullanılabilmektedir. Örneğin, haberlerin turizm talebine etkisinin anlaşılması (Stepchenkova ve Eales, 2011), krizlerden sonra destinasyon imajının iyileştirilmesi (Avraham ve Ketter, 2017) ve destinasyonun turizmdeki mevcut durumunun (Mayaka ve Prasad, 2012) anlaşılması 
amacıyla haber analizleri gerçekleştirilmiştir. Bu araştırmada Balıkesir turizminin yerel haberlerde nasıl yer aldığının ortaya çıkarılması amacıyla erişim kolaylığı, hızlı ve güncel olması (Ayhan ve Kükrer Aydın, 2015, s. 76; Karaduman, 2005, s. 146-147) ve haber çeşitliliği sağlaması (Halıc1, 2005, s. 158) açısından internet haberleri incelenmiştir. Balıkesir turizminin mevcut durumunun medyadaki yansımasının anlaşılması tanıtım, şehrin geleceği için öngörülen düzenlemeler ve politikalara yönelik iyileştirmeler açısından aydınlatıcı olabileceği için araştırmanın sektöre fayda sağlayacağı düşünülmektedir. Balıkesir ve ilçeleri iç turizm bakımından önemlidir. Bu nedenle, araştırmada yerel gazetelerin incelenmesinin daha yansıtıcı olacağına karar verilmiştir. Balıkesir turizmine ilişkin özelliklerin medyada yansıtıldığ1 şekliyle bütüncül olarak anlaşılabilmesi için tek durum deseni kullanılmışır (Yıldıım ve Şimşek, 2013, s.83). Veriler doküman incelemesi yoluyla elde edilmiştir. Doküman incelemesi, kanitlardan yola çıkılarak bütüncül resme ulaşılmaya çalışılan bir yöntemdir (Yıldırım ve Şimşek, 2016, s. 189).

Basın İlan Kurumu'nun resmî web sayfasındaki Balıkesir başlı̆̆ altında yer alan yerel gazeteler taranmıştır. Ayvalık, Bandırma, Burhaniye, Edremit, Erdek, Gömeç, Gönen, Manyas, Sındırgı olmak üzere dokuz ilçede ve merkezde toplam 26 yerel gazete incelemeye tabi tutulmuş, turizm haberi içeren 19 gazete değerlendirmeye alınmıştır. Yerel gazetenin web sayfalarında "Balıkesir" ve "Turizm" anahtar kelimeleri birlikte taranmıştır. Daha güncel haberlere ulaşabilmek amacıyla veri toplama süreci, 1 Ocak 2019- 31 Ağustos 2019 tarihleri arasında yılın ilk sekiz ayını kapsayan tarih aralığıyla sınırlandırılmışır. Bu sınırlama ile elde edilen veriler, 2019 yılı Balıkesir turizmine yönelik gelişmelere ve değişimlere 1şık tutmaktadır.

Elde edilen veriler tematik analiz yöntemiyle değerlendirilmiştir (Glesne, 2015, s. 259). Haber içerikleri ve başlıkları birlikte değerlendirilerek kodlamalar yapılmış, kategori ve temalar oluşturulmuştur. Kodlama, kategori ve temaların belirlenmesinde araştırmacıların fikir birliği göz önünde bulundurulmuştur. Geriye dönük olarak yapılan incelemede haberler hem içerik ve hem de sayısal yönden incelenmiştir. Kod, kategori ve temaların sıklıklarının belirlenebilmesi için Microsoft Excel kullanılmışır. İlçelere, gazetelere ve aylara göre haber sıklıkları nelerdir, öne çıkan temalar nelerdir ve ilçelere göre dağılımları nasıldır gibi araştırma sorularına cevap aranmıstır.

Tablo 1'de Balıkesir ili turizmine ilişkin haber içeren yerel internet gazetelerinin isimleri ve bu gazetelerde karşlaşılan turizm haberlerinin sayıları yer almaktadır. Tablo 1 incelendiğinde Balıkesir turizmine ilişkin haber içeren 19 yerel internet gazetesi olduğu ve bu gazetelerin haber sayısının toplam 207 olduğu görülmektedir. 42 haber ile en fazla turizm haberine Yeni Erdek gazetesinde yer verilmiştir. Yeni Erdek gazetesini 28 haberle Balıkesir Politika ve Memleket gazeteleri takip etmektedir. En az haber sayısına sahip olan gazete ise 1 haber ile Önce Körfez gazetesi olmuştur.

Tablo 1. Turizm Haberi İ̧eren Yerel Internet Gazeteleri ve Haber Saynlan

\begin{tabular}{lc}
\hline \multicolumn{1}{c}{ Yerel İnternet Gazeteleri } & Turizm Haberi Sayılart \\
\hline Edremit-Önce Körfez & 1 \\
Ayvalık-Sözcü & 2 \\
Bandırma-Banses & 4 \\
Bandırma-Yaşam & 5 \\
Merkez-Balıkesir Birlik & 5 \\
Merkez-Balıkesir Ekspres & 5 \\
Merkez-Marmara Bölge & 5 \\
Edremit-Körfez Star & 6 \\
Merkez-Haberci & 6 \\
Edremit-Ege Gündem & 7 \\
Merkez-Yeni Gazetem & 7 \\
Merkez-Yenisöz & 7 \\
Erdek-Erdek Doğuş & 11 \\
Edremit-Körfezde Olay & 12 \\
Merkez-Büyükşehir Merhaba & 12 \\
Merkez-Demokrat & 14 \\
Edremit-Memleket & 28 \\
Merkez-Balıesir Politika & 28 \\
Erdek-Yeni Erdek & 42 \\
Toplam & 207 \\
\hline
\end{tabular}

Tablo 2'de turizm haberlerine ilişkin tema, kategori ve kod sayılarına yer verilmiştir. Tablo 2 incelendiğinde toplam tema sayısının 7, toplam kategori sayısının 40 ve toplam kodlama sayısının ise 228 olduğu tespit edilmiştir. Turizm haberleri çevre, etkinlik, koruma, turizm potansiyeli, pazarlama, talep, yerel yönetimlerin projeleri ve vaatleri başlıkları altında temalandırılmıştır. Bazı haberler için birden fazla 
kodlama yapılmıştır. Turizm potansiyeli teması altında 58 , etkinlik teması altında 56, çevre teması altında 48 , talep teması altında 21 , yerel yönetimlerin projeleri ve vaatleri teması altında 17 , pazarlama temas1 altında 15 ve son olarak koruma teması altında 13 kodlama yapılmıştır. En yoğun kod sayısına sahip olan tema turizm potansiyeli, en az kod sayısına sahip tema ise koruma teması olmuştur.

Tablo 2. Tema, Kategori ve Kodlama Sayllar

\begin{tabular}{|c|c|c|}
\hline Temalar & Kategoriler & Kod Sayılar1 \\
\hline \multirow{6}{*}{ ÇEVRE } & Altyap1 Eksikliği & 7 \\
\hline & Altyap1 Katk1s1 & 21 \\
\hline & Çevresel Etki & 7 \\
\hline & Denetim & 5 \\
\hline & Eleştiri & 5 \\
\hline & Diğer & 3 \\
\hline \multirow{5}{*}{ ETKİNLİK } & Ĕ̆itim Etkinliği & 14 \\
\hline & Gastronomi Etkinliği & 2 \\
\hline & Kültür Etkinliği & 25 \\
\hline & Spor Etkinliği & 5 \\
\hline & Turizmi Geliştirme Çalıșmaları & 10 \\
\hline \multirow{2}{*}{ KORUMA } & Doğal Alanları Koruma & 6 \\
\hline & Kültürel Değerleri Koruma & 7 \\
\hline \multirow{19}{*}{ TURİZM POTANSİYELİ } & Av Turizmi & 1 \\
\hline & Bisiklet Turizmi & 2 \\
\hline & Dalış Turizmi & 1 \\
\hline & Doğa Turizmi & 6 \\
\hline & Etkinlik Turizmi & 1 \\
\hline & Gastronomi Turizmi & 1 \\
\hline & İnanç Turizmi & 1 \\
\hline & Jeoturizm & 2 \\
\hline & Kirsal Turizm & 1 \\
\hline & Kly1 Turizmi & 7 \\
\hline & Kültür Turizmi & 1 \\
\hline & Medikal Turizm & 1 \\
\hline & Sağllk Turizmi & 3 \\
\hline & Sosyal Turizm & 4 \\
\hline & Spor Turizm & 5 \\
\hline & Tarih Turizmi & 3 \\
\hline & Termal Turizm & 9 \\
\hline & Turizm Çeşitliliğ & 5 \\
\hline & Diğer & 4 \\
\hline \multirow{3}{*}{ PAZARLAMA } & Markalaşma & 5 \\
\hline & Tanitım & 7 \\
\hline & Yatırım & 3 \\
\hline \multirow{3}{*}{ TALEP } & Talep Yetersizliği & 4 \\
\hline & Turizm Talebinin Etkisi & 4 \\
\hline & Yoğun Turizm Talebi & 13 \\
\hline \multirow{2}{*}{ YEREL YÖNETİMLERİN PROJELERİ VE VAATLERİ } & Turizmin Çeşitlendirmesi & 8 \\
\hline & Turizmin Geliştirilmesi & 9 \\
\hline Toplam & & 228 \\
\hline
\end{tabular}

\section{Bulgular}

Araştırmada Ocak-Ağustos dönemine ilişkin 12 yerel internet gazetesinde sunulan haberler incelenmiştir. İncelenen gazete haberleri içinde toplam 207 haberin Balıkesir turizmiyle ilişkili olduğu görülmüştür. 7 yerel gazetede Balıkesir turizmi ile ilgili habere ulaşılamamıştır. Şekil 1'de Balıkesir iline ait turizm haberlerine ilişkin sayıların aylara göre dağılımı yer almaktadır. Şekil incelendiğinde en az haberin Ocak ayında, en fazla haberin ise Ağustos ayında yayınlandığı anlaşılmaktadır. 


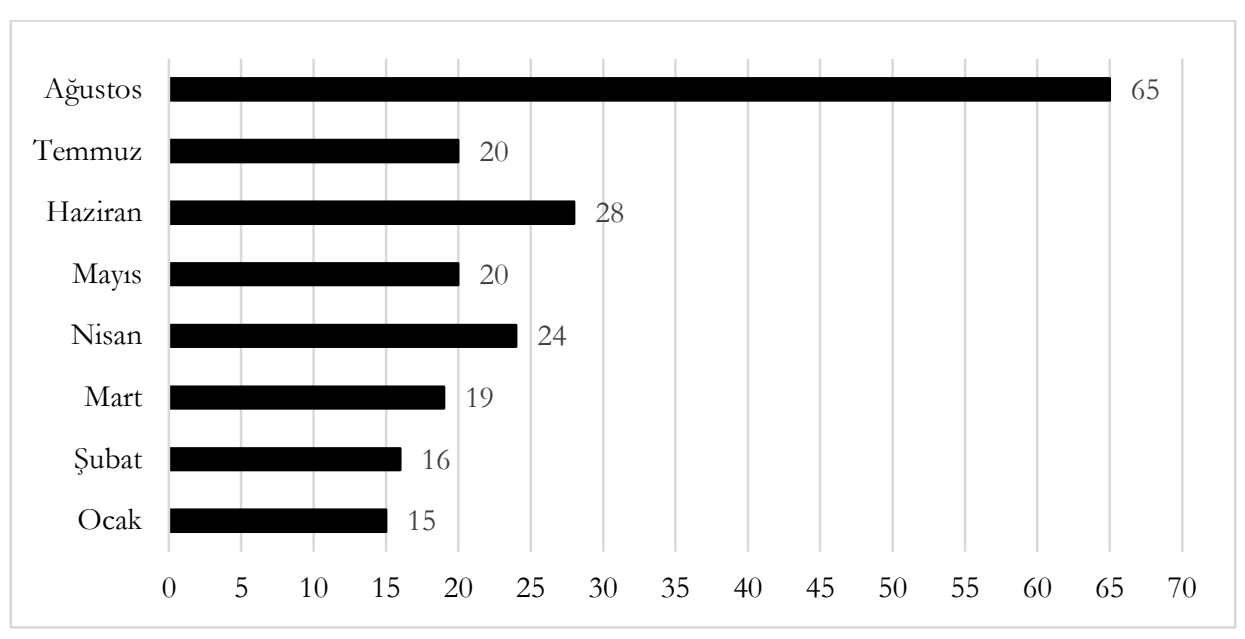

Şekil 1. Aylara Göre Haber Sayısı

Tablo 3'te ilçeleri konu alan turizm haber sayıları yer almaktadır. Balıkesir ili genelinde yayınlanan turizm haberi sayıs 47 iken, Edremit ilçesini konu alan haber sayıs1 42, Erdek ilçesini konu alan haber sayısı 39, Ayvalık ilçesini konu alan haber sayısı ise 26'dır. En fazla turizm haberinin Balıkesir ili genelinde yapıldığı anlaşılmaktadır. En az haber sayısı ise 1 haber ile Gömeç ilçesine aittir.

Tablo 3. Ilçeleri Konu Alan Turizm Haberlerinin Sayısı

\begin{tabular}{|c|c|}
\hline İlçelet & Turizm Haberi Sayılant \\
\hline Gömeç & 1 \\
\hline Gönen & 2 \\
\hline Karesi & 2 \\
\hline Bigadiç & 2 \\
\hline Marmara Adas 1 & 6 \\
\hline Havran & 7 \\
\hline Bandırma & 11 \\
\hline Sindirg1 & 11 \\
\hline Burhaniye & 15 \\
\hline Ayvalık & 26 \\
\hline Erdek & 39 \\
\hline Edremit & 42 \\
\hline Balıkesir & 47 \\
\hline
\end{tabular}

Tablo 4'te turizm haberlerine ilişkin temalara ve kategorilere ait kodlamaların ilçelere göre dağglımları yer almaktadır. Tablo incelendiğinde, Balıkesir merkezinin ve 11 ilçesinin farklı turizm haberi temaları altında yer aldığ1 görülmektedir. 67 haber ile Balıkesir temalarda en fazla kodlanan alan bölge olmuştur. Balıkesir ilini, Erdek (41 kodlama), Edremit (38 kodlama) ve Ayvalık (25 kodlama) ilçeleri takip etmektedir. Turizm potansiyeli ve etkinlik temaları en fazla kodlanan temalardır. 
Tablo 4. Turiz̧m Haberi Temalarmın İlcelere Göre Dağılımı ve Kodlama Sayıları

\begin{tabular}{|c|c|c|c|c|c|c|c|c|c|c|c|c|c|}
\hline Temalar ve Kategoriler/İlçeler & 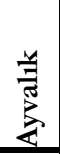 & 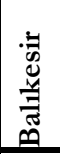 & 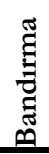 & 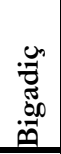 & 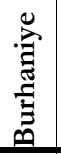 & 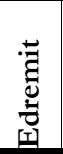 & 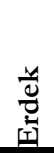 & 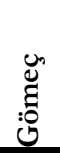 & $\begin{array}{l}5 \\
0 \\
0 \\
0 \\
0\end{array}$ & 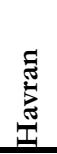 & 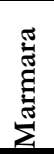 & 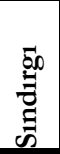 & 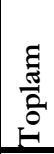 \\
\hline ÇEVRE & 6 & 10 & 3 & & 3 & 15 & 11 & & & & & & 48 \\
\hline Altyapı Eksikliği & 2 & & 1 & & & 1 & 3 & & & & & & 7 \\
\hline Altyapı Katkisi & 1 & 5 & 1 & & 2 & 10 & 2 & & & & & & 21 \\
\hline Cevresel Etki & & & & & & 3 & 4 & & & & & & 7 \\
\hline Denetim & & 2 & & & 1 & 1 & 1 & & & & & & 5 \\
\hline Diğer & & 1 & 1 & & & & 1 & & & & & & 3 \\
\hline Elestiri & 3 & 2 & & & & & & & & & & & 5 \\
\hline ETKINLIK & 9 & 11 & 6 & 1 & 10 & 6 & 6 & & 1 & & 3 & 3 & 56 \\
\hline Eğitim Etkinliği & 4 & 6 & & & 2 & & 1 & & 1 & & & & 14 \\
\hline Gastronomi Etkinliği & 1 & & & 1 & & & & & & & & & 2 \\
\hline Kültür Etkinliği & & 5 & 4 & & 5 & 4 & 2 & & & & 3 & 2 & 25 \\
\hline Spor Etkinliği & 2 & & & & 3 & & & & & & & & 5 \\
\hline Turizmi Gelistirme Calismalar & 2 & & 2 & & & 2 & 3 & & & & & 1 & 10 \\
\hline KORUMA & 4 & & & & & 5 & 3 & & & 1 & & & 13 \\
\hline Doğal Alanlar Koruma & 3 & & & & & 3 & & & & & & & 6 \\
\hline Kültürel Değerleri Koruma. & 1 & & & & & 2 & 3 & & & 1 & & & 7 \\
\hline TURIZM POTANSIYELI & 2 & 28 & & & 4 & 6 & 8 & & & 3 & & 7 & 58 \\
\hline Av Turizmi & & 1 & & & & & & & & & & & 1 \\
\hline Bisiklet Turizmi & & & & & 2 & & & & & & & & 2 \\
\hline Dahs Turizmi & & & & & 1 & & & & & & & & 1 \\
\hline Diger & & 2 & & & & 2 & & & & & & & 4 \\
\hline Doğa Turizmi & 1 & 1 & & & & 1 & 1 & & & & & 2 & 6 \\
\hline Etkinlik Turizmi & 1 & & & & & & & & & & & & 1 \\
\hline Gastronomi Turizmi & & 1 & & & & & & & & & & & 1 \\
\hline Inanc Turizmi & & & & & & & 1 & & & & & & 1 \\
\hline Jeoturizm & & & & & & & 2 & & & & & & 2 \\
\hline Korsal Turizm & & 1 & & & & & & & & & & & 1 \\
\hline Kıyı Turizmi & & 6 & & & 1 & & & & & & & & 7 \\
\hline Kültür Turizmi & & 1 & & & & & & & & & & & 1 \\
\hline Medikal Turizm & & & & & & 1 & & & & & & & 1 \\
\hline Sağllk Turizmi & & 3 & & & & & & & & & & & 3 \\
\hline Sosyal Turizm & & & & & & 1 & 3 & & & & & & 4 \\
\hline Spor Turizmi & & 5 & & & & & & & & & & & 5 \\
\hline Tarib Turizmi & & & & & & & & & & 3 & & & 3 \\
\hline Termal Turizm & & 4 & & & & & & & & & & 5 & 9 \\
\hline Turizm Cessittiliği & & 3 & & & & 1 & 1 & & & & & & 5 \\
\hline PAZARLAMA & & 3 & 1 & 1 & & 4 & 4 & & 1 & 1 & & & 15 \\
\hline Markalașma & & 1 & & 1 & & 1 & & & 1 & 1 & & & 5 \\
\hline Tanttım & & 2 & 1 & & & 2 & 2 & & & & & & 7 \\
\hline Yatirm & & & & & & 1 & 2 & & & & & & 3 \\
\hline$T A L E P$ & 2 & 10 & 1 & & & 2 & 3 & & & & 2 & 1 & 21 \\
\hline Talep Yetersizliği & & 1 & 1 & & & & 2 & & & & & & 4 \\
\hline Turizm Talebinin Etkisi & & 2 & & & & & 1 & & & & & 1 & 4 \\
\hline Yoğun Turizm Talebi & 2 & 7 & & & & 2 & & & & & 2 & & 13 \\
\hline 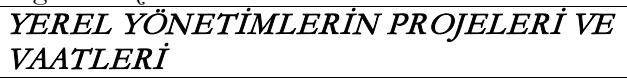 & 2 & 5 & & & & & 6 & 1 & & 2 & 1 & & 17 \\
\hline Turizmin Cesittlendirmesi & 1 & 2 & & & & & 3 & 1 & & 1 & & & 8 \\
\hline Turizmin Gelistirilmesi & 1 & 3 & & & & & 3 & & & 1 & 1 & & 9 \\
\hline Toplam & 25 & 67 & 11 & 2 & 17 & 38 & 41 & 1 & 2 & 7 & 6 & 11 & $\begin{array}{l}22 \\
8\end{array}$ \\
\hline
\end{tabular}

Tablo 5’te çevre temasına, temaya yönelik kategorilere ve kodlara yer verilmektedir. Bu tema altında; altyap1 eksikliği, altyap1 katkısı, çevresel etki, denetim, eleştiri ve diğer olarak isimlendirilen kategoriler sunulmaktadır. Tabloda, Edremit ve Erdek ilçelerine ilişkin çevre temalı haberlerin daha fazla kodlandığ1 anlaşılmaktadır. Haberlerde altyapının geliştirilmesi için yapılan çalışmalara daha fazla yer verilmektedir. Bu tema altında en sık kodlanan haber, Kazdağları'na Cam Seyir Terası Projesi'ne ilişkindir. Edremit'te madenlerin turizme yaptığı olumsuz etki, Erdek'te ise Mavi Bayrak, çevre temizliği, kimyasal sanayiye tepki ve ağaçlara verilen zararlarla ilgili haberler ve eleştiri içeren haberler, çevre bilinci ve duyarllığın haberlere yansıması açısından dikkat çekmektedir. 
Tablo 5. Cevre Temasina İliskin Kategoriler ve Kodlar

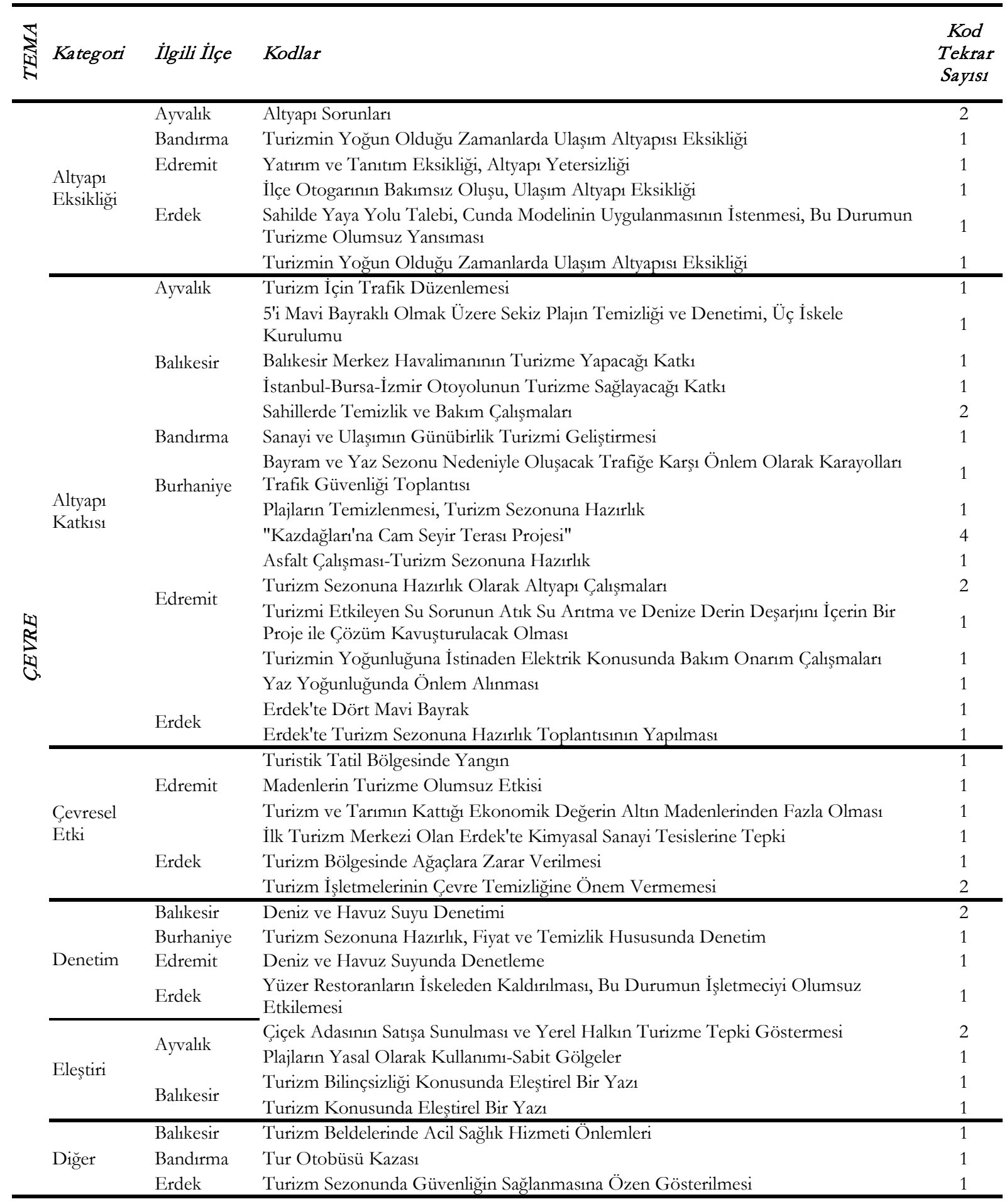

Tablo 6'da etkinlik temasına ilişkin kategoriler ve kodlar yer almaktadır. Etkinlik teması altında eğitim etkinliği, gastronomi etkinliği, kültür etkinliği, spor etkinliği ve turizmi geliştirme çalışmaları kategorileri yer almaktadır. Bu tema altında en yoğun kodlanan kategori, kültür ve eğitim etkinlikleridir. Balıkesir, Burhaniye ve Ayvalık ilçelerine yönelik haberlerin bu temada daha fazla kodlandığı anlaşılmaktadır. Ayrıca, Balıkesir'in etkinlik yönünden oldukça zengin bir il olduğu anlașılmakta ve festivaller dikkat çekmektedir. Tema altında en sık tekrar edilen kodların Burhaniye Ören Turizm Kültür ve Sanat Festivali, Uluslararası Bandırma Kuş Cenneti Kültür ve Turizm Festivali, Turizm Haftası Kapsamında Geleneksel El Sanatları Sergisi ve Avşa Turizm Festivali olduğu görülmektedir. 
Tablo 6. Etkinlik Temasna İliskin Kategoriler ve Kodlar

\begin{tabular}{|c|c|c|c|c|}
\hline$\underset{\mathbb{I}}{\mathbb{S}}$ & Kategori & İgili İlçe & Kodlat & $\begin{array}{c}\text { Kod } \\
\text { Tekrat } \\
\text { Say1s1 }\end{array}$ \\
\hline \multirow{34}{*}{ 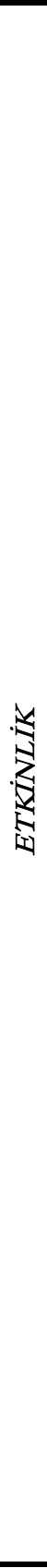 } & \multirow{12}{*}{$\begin{array}{l}\text { Ĕgitim } \\
\text { Etkinliği }\end{array}$} & \multirow{4}{*}{ Ayvalik } & "Plajına Sahip Etkinliği"-- Susurluk'tan Çocukların Ayvalık Ziyareti & 1 \\
\hline & & & Cunda Uygulama Oteli'nin Proje Okulu Olması & 3 \\
\hline & & & Balıkesir Üniversitesi Turizm Fakültesi 21 Şubat Dünya Rehberler Günü Etkinliği & 1 \\
\hline & & & $\begin{array}{l}\text { Balıkesir Üniversitesi Turizm Fakültesi Gastronomi ve Mutfak Sanatları Bölümü } \\
\text { Hakkında Bilgilendirme }\end{array}$ & 1 \\
\hline & & \multirow{4}{*}{ Balıkesir } & $\begin{array}{l}\text { Balıkesir Üniversitesi Turizm Fakültesi Gastronomi ve Mutfak Sanatları Bölümü } \\
\text { Öğrencilere Seminer }\end{array}$ & 1 \\
\hline & & & $\begin{array}{l}\text { Balıkesir Üniversitesi Turizm Fakültesi Öğretim Üyesine Emeklilik Sebebiyle 40. Yıl } \\
\text { Özet Etkinliği }\end{array}$ & 1 \\
\hline & & & $\begin{array}{l}\text { Balıkesir Üniversitesi Turizm Fakültesi ve Balıkesir Üniversitesi Turizm Araştırma ve } \\
\text { Uygulama Merkezi Etkinliği }\end{array}$ & 1 \\
\hline & & & Balıkesir Üniversitesi Turizm Fakültesinde İstihdam ve Kariyer Günleri & 1 \\
\hline & & \multirow[t]{2}{*}{ Burhaniye } & $\begin{array}{l}\text { Baçem'de (Balıkesir Çiftçi Ë̆itim ve Üretim Merkezi) Gerçekleştirilen "Tarladan Hasada } \\
\text { Aromaterapi Eğitim Festivali"nin Turizme Sağlayacağ1 Katk1 }\end{array}$ & 1 \\
\hline & & & Burhaniye Meslek Yüksekokulu Etkinliği & 1 \\
\hline & & Erdek & Turizm Haftası Etkinliği & 1 \\
\hline & & Gönen & Gönen Meslek Yüksekokulu Etkinliği & 1 \\
\hline & \multirow{2}{*}{$\begin{array}{l}\text { Gastronomi } \\
\text { Etkinliği }\end{array}$} & Ayvalık & 28-30 Haziran 2019 "Ayvalık Gastronomisine Yolculuk Günleri" Etkinliği & 1 \\
\hline & & Bigadiç & $\begin{array}{l}\text { 5. Bigadiç Et ve Süt Festivali Kapsamında Turizmi Tanıtıcı Sinevizyon Gösterisi } \\
\text { Sunulması }\end{array}$ & 1 \\
\hline & \multirow{10}{*}{$\begin{array}{l}\text { Kültür } \\
\text { Etkinliği }\end{array}$} & \multirow{2}{*}{ Balıkesir } & Asırlık Gelenek Şamlı Festivali Başladı & 2 \\
\hline & & & Turizm Haftası Kapsamında Geleneksel El Sanatları Sergisi & 3 \\
\hline & & Bandirma & Uluslararası Bandırma Kuş Cenneti Kültür ve Turizm Festivali & 4 \\
\hline & & Burhaniye & "Burhaniye Ören Turizm Kültür ve Sanat Festivali" & 5 \\
\hline & & \multirow{3}{*}{ Edremit } & "Zeytinli Rock Festivali" & 2 \\
\hline & & & Aeneas Rotası Projesi'nin İstanbul'da Görüşülmesi & 1 \\
\hline & & & Sinan Tortum- "Adım Adım Edremit Turu" Etkinliği & 1 \\
\hline & & Erdek & "Kyzikos Antik Kenti Konulu Seminer" & 2 \\
\hline & & Marmara & "Avşa Turizm Festivali" & 3 \\
\hline & & Sindırg1 & "21. Uluslararası Sındırg1 Yağcıbedir Halı, Kültür ve Sanat Günleri" & 2 \\
\hline & \multirow{3}{*}{$\begin{array}{l}\text { Spor } \\
\text { Etkinliği }\end{array}$} & Ayvalik & "6. Ultimate Cunda Yarışları" & 2 \\
\hline & & \multirow{2}{*}{ Burhaniye } & "5. Burhaniye Bisiklet Festivali" & 1 \\
\hline & & & "6. Burhaniye-Kızıklı Yağlı Pehlivan Güreşleri" & 2 \\
\hline & \multirow{7}{*}{$\begin{array}{l}\text { Turizmi } \\
\text { Geliştirme } \\
\text { Çalışmaları }\end{array}$} & Ayvalık & 30 Eylül-06 Ekim "Çinli Tur Operatörleri Buluşması" Programı & 2 \\
\hline & & Bandirma & Şehir Çalıştayı'nda Turizm Konusunun Ele Alınması & 2 \\
\hline & & \multirow{2}{*}{ Edremit } & $\begin{array}{l}\text { Edremit'te Termal Turizm Atağ1 25-29 Eylül } 2019 \text { "4. Uluslararası Termal ve Sağlık } \\
\text { Turizm Zirvesi" Hazırllğı }\end{array}$ & 1 \\
\hline & & & $\begin{array}{l}\text { Tüketici Mevzuatı ve Sağlık, Turizm ve Reklam Konularında Konularına "Devre Mülk } \\
\text { Devre Tatil Çalıstayı" }\end{array}$ & 1 \\
\hline & & \multirow{2}{*}{ Erdek } & Erdek'te Jeoturizm Paneli & 2 \\
\hline & & & Kapıdağ Yarımadası'nın Jeoturizm Potansiyeli Paneli & 1 \\
\hline & & Sindırg1 & $\begin{array}{l}\text { 25-29 Eylül } 2019 \text { "4. Uluslararası Termal ve Sağlık Turizm Zirvesi" Kapsamında Acenta } \\
\text { Tanıtım Turları }\end{array}$ & 1 \\
\hline
\end{tabular}

Tablo 7'de koruma teması altında yer verilen kategoriler ve kodlamalar bulunmaktadır. Koruma teması altında doğal alanları koruma ve kültürel değerleri koruma kategorileri yer almaktadır. Her iki kategorinin kodlanma sayısı birbirine çok yakındır. Edremit ve Ayvalık ilçelerine yönelik haberlerin bu temada daha fazla kodlandığı anlaşılmaktadır. 
Tablo 7. Koruma Temasina Illiskin Kategoriler ve Kodlar

\begin{tabular}{|c|c|c|c|c|}
\hline 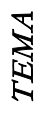 & Kategori & İgili İlçe & Kodlat & $\begin{array}{c}\text { Kod } \\
\text { Tekrat } \\
\text { Sayisı }\end{array}$ \\
\hline \multirow{9}{*}{ 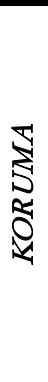 } & \multirow{4}{*}{$\begin{array}{l}\text { Doğal Alanları } \\
\text { Koruma }\end{array}$} & \multirow{2}{*}{ Ayvalık } & "Ayvalık Doğal Yaşamı Koruyor" Projesi & 1 \\
\hline & & & Badavut'un Kesin Korunacak Hassas Alan İlan Edilmesi & 2 \\
\hline & & \multirow{2}{*}{ Edremit } & Kazdağları'nın Dünya Mirası Olması & 1 \\
\hline & & & Kazdağları'nın Korunması & 2 \\
\hline & \multirow{5}{*}{$\begin{array}{l}\text { Kültürel } \\
\text { Değerleri } \\
\text { Korum }\end{array}$} & Ayvalık & $\begin{array}{l}\text { Ayazma'nın Restore Edilip Turizme Kazandırılması, Altınova Sahilinin Yapılması, Paşa } \\
\text { Limanı'nın Yapılması }\end{array}$ & 1 \\
\hline & & Edremit & "Tarihi Edremit Evleri Günyüzüne Çıkıyor" Projesi & 2 \\
\hline & & \multirow{2}{*}{ Erdek } & Açık Hava Müzesindeki Tarihi ve Arkeolojik Eserlerin Zarar Görmesi & 1 \\
\hline & & & Tahrip Edilen Tarihi Eserlerin Temizlenmesi & 2 \\
\hline & & Havran & Eski Evlerin Yenileme Çalışmaları, Balıkesir'e Kazandırılması & 1 \\
\hline
\end{tabular}

Tablo 8'de turizm potansiyeli teması altında belirlenen kategoriler ve kodlar yer almaktadır. Turizm potansiyeli teması altında av turizmi, bisiklet turizmi, dalıs turizmi, diğer, doğa turizmi, etkinlik turizmi, gastronomi turizmi, inanç turizmi, jeoturizm, kırsal turizm, kıyı turizmi, kültür turizmi, medikal turizm, sağllk turizmi, sosyal turizm, spor turizmi, tarih turizmi, termal turizm ve turizm çeşitliliği kategorileri yer almaktadır. Bu tema altında en yoğun kodlanan kategoriler sırasıyla termal turizm, kıyı turizmi ve doğa turizmidir. Balıkesir, Erdek, Sındırg1 ve Edremit ilçelerine yönelik haberlerin bu temada daha fazla kodlandığ1 anlaşılmaktadır. Balıkesir’in denizi, tarihi, kültürel ve doğal güzellikleriyle görülmesi gereken bir şehir olması sıklıkla tekrarlanmaktadır. Ayrıca, bu tema altında Balıkesir'de spor turizmi ve Sindırgı'da termal turizmle ilgili haberler öne çıkmaktadır.

Tablo 8. Turizm Potansiyeli Temasna İlişkin Kategoriler ve Kodlar

\begin{tabular}{|c|c|c|c|c|}
\hline 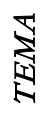 & Kategori & İlgili İlçe & Kodlar & $\begin{array}{c}\text { Kod } \\
\text { Tekrar } \\
\text { Say1s1 }\end{array}$ \\
\hline \multirow{24}{*}{ 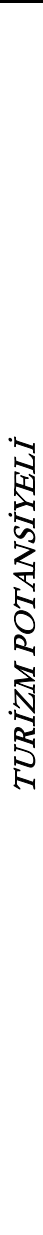 } & Av Turizmi & Balıkesir & Av Bașina Günlük Avlanma Limitlerinin Açılanması & 1 \\
\hline & Bisiklet & P & 5. Burhaniye Bisiklet Festivali'nin Turizmin Cesitlendirilmesine Destek Olması & 1 \\
\hline & Turizmi & Burnanilye & Bisiklet Turizminin Bölgede Geliştirilmesi & 1 \\
\hline & Dalış Turizmi & Burhaniye & "Dalış Turizm Merkezi" Projesi, Yapay Resif Projesi & 1 \\
\hline & \multirow{5}{*}{ Doğa Turizmi } & Ayvalık & Ekolojik Zenginliklerin Sürdürülebilir Turizm Kapsamında Kullanılması & 1 \\
\hline & & Balıkesir & $\begin{array}{l}\text { Turizmin } 12 \text { Aya Yayılması, Doğa Turizmi, Kıyı Turizmi ve Termal Turizmin } \\
\text { Geliştirilmesi }\end{array}$ & 1 \\
\hline & & Edremit & Denizden Çıkan Tatlı Su & 1 \\
\hline & & Erdek & $\begin{array}{l}\text { Kapıdağ'da Doğa Turizmi, Engelli Turizm ve Ekolojik Tarım Atölyesi Projesi } \\
\text { Hazırlanmas1-"Gelecek Turizmde" Konulu Proje Çağrısına Kabul Edildi }\end{array}$ & 1 \\
\hline & & Sindirg1 & Sındırg1 Lavanta Hasatı'nın Turizmde Kullanılma Potansiyelinin Olması & 2 \\
\hline & $\begin{array}{l}\text { Etkinlik } \\
\text { Turizmi }\end{array}$ & Ayvalık & $\begin{array}{l}\text { Ayvalık'ın Konferans ve Uluslararası Festivaller Turizmi Açısından Önemli } \\
\text { Olması }\end{array}$ & 1 \\
\hline & $\begin{array}{l}\text { Gastronomi } \\
\text { Turizmi }\end{array}$ & Balıkesir & Balıkesir Gastronomi Turizminin Rekabet Gücü & 1 \\
\hline & İnanç Turizmi & Erdek & Göktaşının İnanç Turizmi Kapsamında Zeytinliada'da Sergilenmesi & 1 \\
\hline & \multirow{2}{*}{ Jeoturizm } & \multirow{2}{*}{ Erdek } & Jeoturizm Konulu Panel, Jeoturizmin Yerel Kalkınmaya Etkisi, Jeoparklar & 1 \\
\hline & & & Kapıdağ Yarımadası'nın Jeoturizm Potansiyeli Paneli & 1 \\
\hline & Kursal Turizm & Balıkesir & $\begin{array}{l}\text { TKDK (Tarım ve Kırsal Kalkınmayı Destekleme Kurumu) Kırsal Turizm ve } \\
\text { Rekreasyon Faaliyetleri Desteği }\end{array}$ & 1 \\
\hline & \multirow{6}{*}{ Kiy1 Turizmi } & \multirow{5}{*}{ Balıkesir } & Balıkesir'de Kiy1 Turizmi & 1 \\
\hline & & & Balıkesir'in Yaz Turizmi Potansiyeli & 1 \\
\hline & & & Eşsiz Kıyılar, Temiz Denizlerin Olması & 2 \\
\hline & & & Mavi Bayraklı Plaj Sayısında Balıkesir 4. Sırada & 1 \\
\hline & & & $\begin{array}{l}\text { Turizmin } 12 \text { Aya Yayılması, Doğa Turizmi, Kıyı Turizmi ve Termal Turizmin } \\
\text { Geliştirilmesi }\end{array}$ & 1 \\
\hline & & Burhaniye & Mavi Bayraklı Plajların Bulunması & 1 \\
\hline & $\begin{array}{l}\text { Kültür } \\
\text { Turizmi } \\
\end{array}$ & Balıkesir & Balıkesir'deki Arkeolojik Varlığın Turizm Alanında Değerlendirilememesi & 1 \\
\hline & $\begin{array}{l}\text { Medikal } \\
\text { Turizm }\end{array}$ & Edremit & Medikal Turizmin Talep Görmesi & 1 \\
\hline & Sağllk Turizmi & Balıkesir & Sağlik Turizmi Potansiyeli & 2 \\
\hline
\end{tabular}




\begin{tabular}{|c|c|c|c|}
\hline & & Balıkesir'in Sağlık Turizminde Ön Plana Çıkarılması & 1 \\
\hline \multirow{2}{*}{ Sosyal Turizm } & Edremit & Yaz Kampı Başvuruları & 1 \\
\hline & Erdek & Kamu Kamplarının Yok Oluşu, Yıkılması & 3 \\
\hline Spor Turizm & Balıkesir & Spor Turizmi Potansiyeli- Triatlon Şampiyonası & 5 \\
\hline Tarih Turizmi & Havran & Havran'ın Tarih Turizmi Merkezine Dönüştürülmesi & 3 \\
\hline \multirow{6}{*}{$\begin{array}{l}\text { Termal } \\
\text { Turizm }\end{array}$} & \multirow{4}{*}{ Balıkesir } & Pamukçu'nun Termal Turizm Merkezi Olması Gerekliliği & 1 \\
\hline & & Termal Turizmde Yabancı Turist İsteği & 1 \\
\hline & & Termal Turizm Kimliği Kazandırılması & 1 \\
\hline & & $\begin{array}{l}\text { Turizmin } 12 \text { Aya Yayılması, Doğa Turizmi, Kıyı Turizmi ve Termal Turizmin } \\
\text { Geliştirilmesi }\end{array}$ & 1 \\
\hline & \multirow{2}{*}{ Sindirg1 } & Sındırgı'da Gelişen Termal Turizm ve Tersine Göç Olaylarının Yaşanması & 4 \\
\hline & & Sındırgi'nın Termal Turizm Potansiyeli ve Yerel Yönetim Projesi & 1 \\
\hline \multirow{4}{*}{$\begin{array}{l}\text { Turizm } \\
\text { Çeşitliliği }\end{array}$} & \multirow{2}{*}{ Balıkesir } & $\begin{array}{l}\text { Balıkesir'in Kıyı Turizmi, Termal Turizm, Kültür Turizmi ve Doğa Turizmi } \\
\text { Potansiyeli }\end{array}$ & 1 \\
\hline & & $\begin{array}{l}\text { İlin Tarihi, Kültürel ve Doğal Güzelliklere Sahip Olması, Zengin Bitki Örtüsü, } \\
\text { İklimi, Coğrafi Özellikleri Bakımından Görülmesi Gereken Şehir Olması }\end{array}$ & 2 \\
\hline & Edremit & Gelecek Vaad Eden, Dağ, Deniz, Sağlik, Kültür Turizmi Potansiyeli & 1 \\
\hline & Erdek & Erdek'in Turizm Potansiyeli, Turizm Çeşitliliği & 1 \\
\hline \multirow{3}{*}{ Diğer } & Balıkesir & Balıkesir'in Turizm Potansiyeli & 2 \\
\hline & \multirow{2}{*}{ Edremit } & Edremit Kaymakamının Turizm ile İlgili Görüşleri & 1 \\
\hline & & Edremit'in Turizm Potansiyeli & 1 \\
\hline
\end{tabular}

Tablo 9'da pazarlama temasına ilişkin kategoriler ve kodlamalar bulunmaktadır. Pazarlama teması altında markalaşma, tanıım ve yatırım kategorileri yer almaktadır. Tablo incelendiğinde markalaşma teması altında Balıkesir ve Bigadiç, Edremit, Gönen ve Havran olmak üzere dört ilçenin bulunduğu haberlerin olduğu görülmektedir. Ancak, bu tema altında en yoğun kodlanan kategori tanıtımdır. Edremit ve Erdek ilçelerine yönelik haberlerin bu temada daha fazla kodlandığı anlaşılmaktadır. Yatırım kategorisi altında ise yeni otel açlışları ve yatırım yetersizlikleri ile ilgili haberler bulunmaktadır. Balıkesir turizmine yönelik haberlerde yatırım konusuna yeterince yer verilmemesi dikkat çekmektedir.

Tablo 9. Pazarlama Temasina İliskin Kategoriler ve Kodlar

\begin{tabular}{|c|c|c|c|c|}
\hline 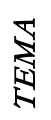 & Kategori & İlgili İlçe & Kodlar & $\begin{array}{c}\text { Kod } \\
\text { Tekrar } \\
\text { Say1s1 }\end{array}$ \\
\hline & \multirow{5}{*}{ Markalaşma } & Balıkesir & Turizm Kimliği Kazandırılması & $\overline{1}$ \\
\hline & & Bigadiç & "Markalaşma Yolunda Bigadiç" Projesi & 1 \\
\hline & & Edremit & Edremit'in Turizmde Marka Şehir Olma Yolunda İlerlemesi & 1 \\
\hline & & Gönen & $\begin{array}{l}\text { Fizik Tedavi ve Rehabilitasyon Uygulama ve Araştırma Merkezi'nin Sağlık Turizminde } \\
\text { Marka Değeri Sağlaması }\end{array}$ & 1 \\
\hline & & Havran & Havran'in Turizmde Marka Kent Haline Getirilmesi & 1 \\
\hline \multirow{9}{*}{ 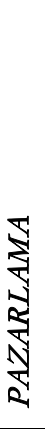 } & \multirow{6}{*}{ Tanitım } & \multirow[t]{2}{*}{ Balıkesir } & $\begin{array}{l}\text { 55. Cumhurbaşkanlığı Türkiye Bisiklet Turu'nun Balıkesir'in Doğal ve Tarihi } \\
\text { Güzelliklerinin Tanıtımına Katkı Sağlaması }\end{array}$ & 1 \\
\hline & & & Balıkesir Malazgirt'te Tanıtımı- Tanıtım Çadıının Kurulması & 1 \\
\hline & & Bandirma & $\begin{array}{l}\text { Kösse Yazısı- Uluslararası Bandırma Kuş Cenneti Kültür ve Turizm Festivali'nde İlçeyi } \\
\text { Simgeleyen Objelerin Kullanılmaması }\end{array}$ & 1 \\
\hline & & \multirow{2}{*}{ Edremit } & İlçenin Emitt Fuarında Tanıtılması & 1 \\
\hline & & & Tanıtım eksikliği & 1 \\
\hline & & Erdek & Erdek'in Turizm Tanitımı & 2 \\
\hline & \multirow{3}{*}{ Yatırım } & Edremit & Yatırım Yetersizliği & 1 \\
\hline & & \multirow{2}{*}{ Erdek } & Butik Otel Açılışı & 1 \\
\hline & & & Konaklama İşletmesi Açllş̧1 & 1 \\
\hline
\end{tabular}

Tablo 10 'da talep temasına yönelik kategoriler ve kodlamalar sunulmaktadır. Talep teması altında talep yetersizliği, turizm talebinin etkisi ve yoğun turizm talebi kategorileri yer almaktadır. Bu tema altında en yoğun kodlanan kategorinin yoğun turizm talebi olduğu ve Balıkesir'e yönelik haberlerin daha fazla kodlandığı anlaşılmaktadır. Ayrıca, Ayvalık, Edremit ve Marmara yoğun turizm talebi ile ilgili haberler yer almaktadır. Ancak, Erdek ve Bandırma'da yeterli talebin olmadığına değinilmektedir. 
Tablo 10. Talep Temasma Illiskin Kategoriler ve Kodlar

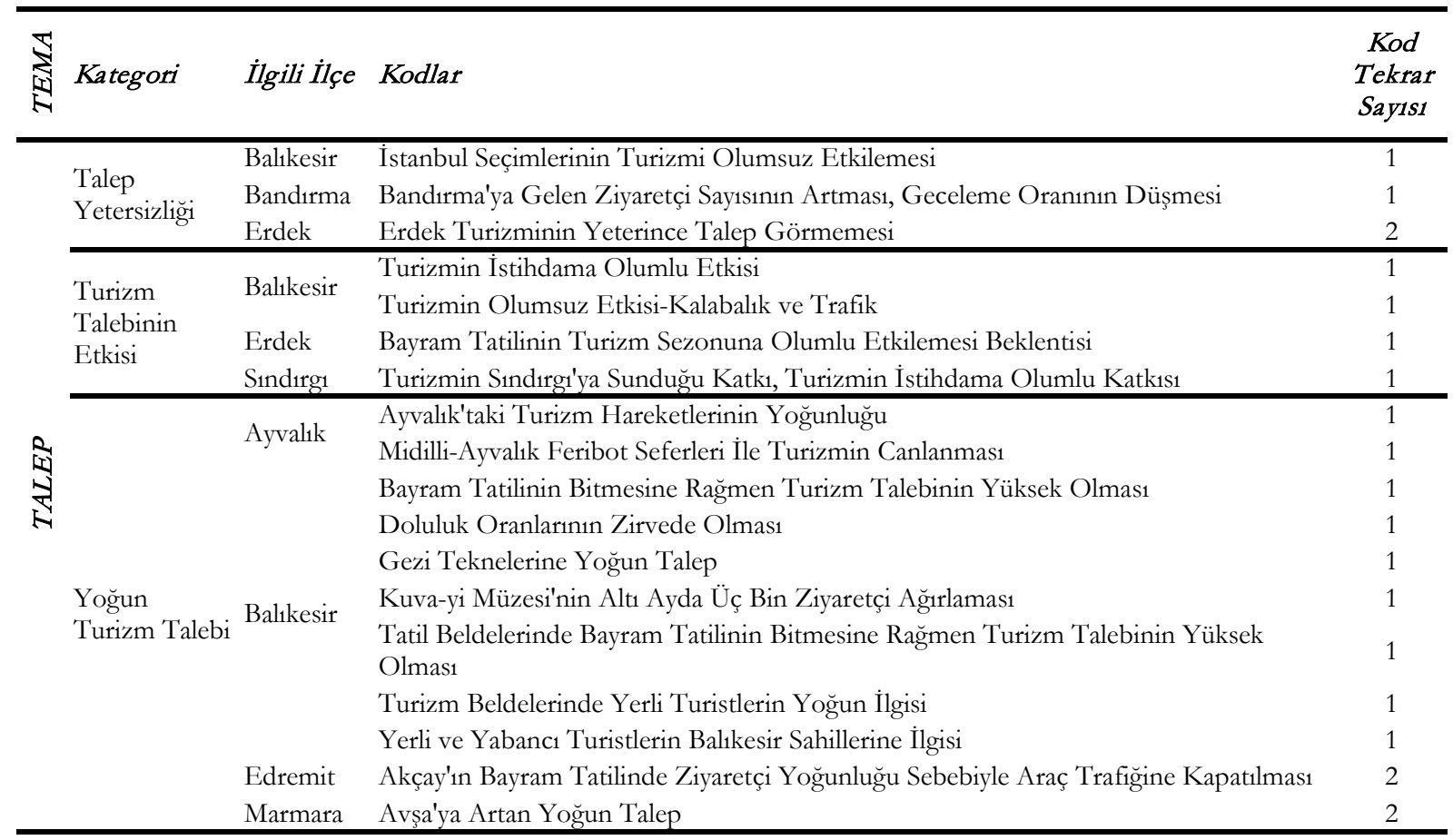

Tablo 11'de turizm haberlerine ilişkin yerel yönetimlerin projeleri ve vaatleri temasına ve bu temaya yönelik kategori ve kodlara yer verilmektedir. Bu temanın altında turizmin çeşitlendirilmesine ve turizmin geliştirilmesine ilişkin kategoriler bulunmaktadır. Her iki kategori altında hem turizmle ilgili genel vaatlere hem de somut projelere yer verildiği görülmektedir. Ayrıca, her iki kategorinin kodlanma sayısı birbirine çok yakındır. Erdek ve Balıkesir'e yönelik haberlerin bu temada daha fazla kodlandığı anlaşılmaktadır.

Tablo 11. Yerel Yönetimlerin Projeleri ve Vaatleri Temasina İlişkin Kategoriler ve Kodlar

\begin{tabular}{|c|c|c|c|c|}
\hline$\underset{4}{\mathbb{A}}$ & Kategori & İlgili $\dot{I} l c ̧ e$ & Kodlat & $\begin{array}{c}\text { Kod } \\
\text { Tekrar } \\
\text { Sayıs1 }\end{array}$ \\
\hline \multirow{4}{*}{$\begin{array}{l}\text { से } \\
\mathbb{N} \\
\mathbb{N} \\
\mathbb{N}\end{array}$} & \multirow{8}{*}{$\begin{array}{l}\text { Turizmin } \\
\text { Çeşitlendirmesi }\end{array}$} & Ayvalık & "İlçenin 12 Ay Süre İle Canlı Kalacağı" Vaadi & 1 \\
\hline & & \multirow[t]{2}{*}{ Balıkesir } & $\begin{array}{l}\text { "Termal Kaynakların Turizme Kazandırılması ve Termal ve Kültür Turizminin } \\
\text { Birleştirilmesi" Vaadi }\end{array}$ & 1 \\
\hline & & & "Turizmin Tüm Çeşitlerini Ön Plana Çıkarmak" Vaadi & 1 \\
\hline & & & $\begin{array}{l}\text { "Kapıdağ Yarımadasında Dağ Turizmi, Erdek'te Yat Turizmi, Zeytinliada'da } \\
\text { Turizm" Vaatleri }\end{array}$ & 1 \\
\hline 过 & & Erdek & $\begin{array}{l}\text { "Zeytinliada'nın Turizme Kazandırılması, Kapıdağ Yarımadasında Dağ } \\
\text { Turizminin Canladırılması, Erdek'te Yat Turizmi Projesi, Sahil Bandının Peyzaj } \\
\text { Düzenlemesi ve Yürüyüş Yollarının Yapılması, Yatak Kapasitesinin ve Kalitesinin } \\
\text { Arttırılarak Pansiyonculuğun Canlandırılması" Vaatleri }\end{array}$ & 1 \\
\hline Oे & & & Erdek'in Turizm Merkezi Olması, Turizmin 12 Aya Yayılmas1 Vaatleri & 1 \\
\hline$\frac{\sigma^{2}}{2}$ & & Gömeç & "Su Sporlar1 Aktivite Merkezi" Projesi & 1 \\
\hline Z & & Havran & "Tarihi Evlerin Kültür Turizmine Açılması" Vaadi & 1 \\
\hline 过 & \multirow{8}{*}{$\begin{array}{l}\text { Turizmin } \\
\text { Geliştirilmesi }\end{array}$} & Ayvalık & $\begin{array}{l}\text { "Ayvalık'ın Turizme Hizmet Edecek Olması" Vaadi } \\
\text { "Edremit'i Turizm Merkezi Yapmak" Vaadi }\end{array}$ & $\begin{array}{l}1 \\
1\end{array}$ \\
\hline : & & Balıkesir & Balıkesir'de Turizmin Geliştirilmesi İle İlgili Yerel Yönetim Projeleri & 1 \\
\hline 过 & & & Turizmi Geliştirileceğine Yönelik Vaad & 1 \\
\hline 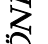 & & & "Erdek'in Turizm Potansiyelinin Arttırılacağı" Vaadi & 1 \\
\hline Dis & & Erdek & $\begin{array}{l}\text { "Turizm Yatırımlarına Önem Verme, İlçeyi En Güzel Turizm Merkezlerinden } \\
\text { Biri Yapmak" Vaadi }\end{array}$ & 1 \\
\hline 这 & & & $\begin{array}{l}\text { Erdek'in Daha Yoğun ve Hareketli Bir Turizm Sezonu Geçirmesi, Limanın } \\
\text { Turizm Amaçlı Kullanılması" Vaadi }\end{array}$ & 1 \\
\hline & & Havran & Havran'in Turizmde Marka Kent Haline Getirilmesi Projesi & 1 \\
\hline & & Marmara & "7/24 Hizmet Verecek Hizlı Feribot" Vaadi & 1 \\
\hline
\end{tabular}




\section{Tartışma, Sonuç ve Öneriler}

Bilgi kaynağı olarak haberler, okurları destinasyon hakkında bilgilendiren önemli unsurlardan biridir. Doğru ve yeterli kullanıldığında turizm açısından da fayda sağlayabilmektedir. Benzer şekilde, yerel gazeteler bir bölgeye ilişkin haberlerin yerel bakış açısından elde edilebilmesi için en faydalı haber araçlarındandır. Günümüzde internet ile güçlenen yerel gazeteler, daha geniş kitlelere ulaşabilme şansı elde etmiş olup birçok farklı konudaki haberi daha fazla sayılda okuyucuya iletebilme imkanına sahiptir. Yerel gazeteler bölgeyi yansıtma işlevini yerine getirmektedir.

İlgili alanyazın incelediğinde, turist ölümlerine ilişkin yapılan çalısmaların yanı sıra, turist kadınların medyada yer alması, turizmin zararı, yavaş şehir olma süreci, imaj, sağlık turizmi, Türk Mutfağı konuları da çalışma alanı bulmuştur. Ayrıca Türkiye ulusal turizm haberlerinin incelenmesi, Trabzon turizm farkındalığı ve Eskişehir turistik çekiciliklerinin ele alınmış olması dikkat çekicidir. Ancak, turizm hareketleri açısından önemli bir şehir olan Balıkesir ilinin turizmine ilişkin yerel gazete haberlerini süzgeçten geçirerek değerlendiren bir çalışmaya rastlanmamıştır. Bu nedenle, Balıkesir turizminin özel olarak ele alınması ve haberlerde yer alan unsurların temalandırılarak Balıkesir turizmi açısından incelenmesi bakımından ilgili alanyazına katkı sağlayacağı düşünülmektedir. Bu kapsamda, araştırmada Balıkesir turizminin çevrimiçi ulaşılabilen yerel gazete haberlerinde nasıl yer aldığının ortaya çıkarılması amaçlanmıştır.

Sonuçlar incelendiğinde, turizmle ilgili haber sayısının az olduğu anlaşılmıştır ve bazı gazete haberlerinde "turizm" anahtar kelimesi aratıldığında herhangi bir haber ile karşılaşılmamıştır. Aslında, turizm olgusunun ulusal yazılı medyada dahi yeterince yer almadığ1 (Kervankıran ve Aktürk, 2016) düşünülürse bu durumun yerel gazete haberlerine de yansımış olduğu anlaşılabilmektedir. Bunun yanı sıra, turizm haberlerinin bazı aylarda ve bazı bölgelerde yoğunlaştığı görülmüştür. Haber sayıları turizmin yoğun olduğu yaz aylarında yoğunlaşmıştır ve kıyı bölgelere ait gazeteler turizmle ilgili daha fazla yayın yapmıştır. $\mathrm{Bu}$ beklenilen bir sonuçtur. Ancak, Gömeç, Gönen, Karesi, Bigadiç, Marmara Adası ve Havran gibi ilçelerin turizmle ilgili haberlerde yer bulamadığı anlaşılımıştır. Araştırma sonucunda özellikle Edremit ve Erdek ile ilgili haberlerin temalarının diğer ilçelerle ilgili haberlere göre daha fazla çeşitliliğe sahip olduğu görülmüştür.

Yılmaz ve Parlak (2017) tarafından yapılan çalısmada Trabzon ilinde turizm konusundaki en büyük eksikliğin altyap1 yetersizliği ve yetersiz turistik tesisler olduğu sonucuna ulaşılmışır. Benzer şekilde bu çalışmada altyap1 eksikliğinin olduğu bulgusu elde edilmiş, haberlerde altyapı sorunları, ulaşım konusunda altyap1 eksikliği özellikle vurgulanmıştır. Şimşek ve Hassan (2018) tarafindan yapılan çalışmada haberler nitelik açıdan incelendiğinde, haberlerin çoğunluğunun bilgi verme amaçlı olduğu sonucuna ulaşılmıştır. Benzer şekilde, Aydın ve Aydın (2020) tarafından da aynı sonuca ulaşmış, bu anlamda yerel gazetelerin bütüncül bir bakış ile yerel bir pazarlama aracı olarak kullanılabileceği önerilmiştir. Bu kapsamda, bu çalışmada yer alan haberler çerçevesinde pazarlama unsurunun varllğ1 ve pazarlama temasının altında markalaşma, tanıtım ve yatırım kategorilerinin bulunması dikkat çekmektedir.

İncelenen haberler doğrultusunda farklı temalar oluşturulmuştur ancak bu temalar arasında sayısal olarak ve haber çeşitliliği bakımından etkinlik, turizm potansiyeli ve çevre temaları ön plana çıkmıştır. Özellikle turizm potansiyeli ve etkinlik temaları çok sık kullanılmıştır. Bu sonuç, destinasyon tanıtımında etkinliklerin ne derece önemli olduğuna ve tanıtım unsuru olarak kullanılabileceğine ilişkin bir kanıt olarak değerlendirilebilir.

Her ilçe için olmasa da Balıkesir'de genel olarak turizm çeşitliliğinin varlığının haberlere yansımış olması Balıkesir'in dört mevsim turizm potansiyeline sahip olduğunu destekler niteliktedir. Ancak, ilginç olarak en az kullanılan temaların pazarlama ve koruma olması, Balıkesir turizminin geleceği açısından düşündürücüdür. Çünkü bu temalar, bir destinasyonda turistlerin karar vermelerini kolaylaştıran ve turistleri destinasyona yönlendiren faktörler olabilmektedir. İncelenen haberler göz önünde bulundurulduğunda karşılaşılan diğer bir sonuç hazırlanan haberlerin oldukça benzer olmasıdır. Hatta bazen aynı haberler, aynı cümlelerle sunulmuştur. Ancak, bu sadece Balıkesir'in yerel haber yayıncillğı ile ilgili bir sorun değildir. Yıldırım ve Karaahmet (2013) tarafından Ordu ilinin Perşembe ilçesinin yavaş şehir olma süreci yerel basın üzerinden değerlendiren çalışmada da bu benzerliğe rastlanmıştır. 
Sonuç olarak, yerel gazetelerin bakış açısından Balıkesir'e bakıldığında; farklı turizm çeşitlerini barındıran, etkinlik sayısı fazla, turizm potansiyeli yüksek, ancak altyapı konusunda yetersizlikleri bulunan ve markalaşma yolunda ilerleyen bir il olduğu görülmektedir. Bu kapsamda, bazı öneriler sunulmuştur.

- Öncelikle, haberler incelenirken benzer içeriğe sahip haberlerle çok sık karșılașılmıștır. Bu nedenle, yerel haberler içerik yönünden özgünlük konusunda eksiklik görülmüştür ve hatta bazı gazete haberlerinde "turizm" anahtar kelimesi aratıldığında herhangi bir haber ile karşılaşılmamıştır. Bu konuda gazetecilere önemli görevler düşmektedir. Ayrıca, yatırım destekleriyle ilgili haberler bölge turizmini destekleyebileceği için bu tip haberlere daha fazla yer verilmesi gerekli görülmüştür.

- Eleştiri yazılarının ve köşe yazılarının ya da destinasyonla ilgili yorumların ve tavsiyelerin sayısının artmasının hem yerel yönetimler için hem de potansiyel ziyaretçiler için yol gösterici ve tanıtıcı olabileceği düşünülmektedir. Ancak, tanıtımda sadece haberlerin kullanılması tek başına yeterli olamamaktadır. Bu nedenle, tanıtımlar televizyon, film, tanıtım filmi ve internet gibi araçlarla desteklenmelidir (Şimşek ve Hassan, 2018).

- Çalısmada, Balıkesir ilinin yerel turizm haberlerinde etkinlik ve turizm çeşitliliği bakımından ön planda olduğu görülmektedir. Bu sebeple etkinlik pazarlaması açısından önemli bir araç olduğu düşünülmektedir.

- Yerel yönetimlerin turizm tanıtımına ilişkin kampanyalara daha fazla bütçe ayırmalarının gerekli olduğu düşünülmektedir.

- Balıkesir ili tanıtımına ilişkin haberlerin etkinliğinin ölçülmesi açısından potansiyel ziyaretçiler üzerinde çalışmalar yapılmasının faydalı olabileceği öngörülmektedir.

- İnternetin sahip olduğu olanaklar değerlendirildiğinde, web sitelerinde bulunan haberlerin merak uyandırması ve harekete geçirmesi beklenilen bir etki olmalıdır. Şehre ilişkin talebi arttırmak için şehri ve şehrin sahip olduğu çekicilikleri yansıtan görseller kullanılabileceği öngörülmektedir (Aydın ve Aydın, 2020, s.116-117). Buradan hareketle, Balıkesir iline ilişkin haberlerde görsel kullanımı, haberi ve şehri daha etkin kılabilmektedir. Haber siteleri, haberlerde ilgi çekici görsel kullanımına özen göstermelidir.

- Gelecek çalışmalarda, sonuçların güçlendirilmesi açısından ulusal gazetelerde Balıkesir turizmi aratılarak ve tarih aralı̆̆ genişletilerek yeni incelemelerin yapılması ve ayrıca gazetecilerle görüşme yapılarak görüşlerinin veya algılarının anlaşılması faydalı olabilir.

Çalışmada Balıkesir ilinin, ilçeleriyle birlikte ele alınması ve tema ve kategoriler altında ilçe bazında da değerlendirilmesi, çalışmayı diğer çalışmalardan farklı kılmaktadır. Çalısmada temalar araştırmacılar tarafından belirlenmiş olup, bu yönüyle ilgili alanyazında yapılacak çalışmalara işı tutabileceği düşünülmektedir.

\section{Etik Beyan}

"Yerel Internet Gazetesi Haberlerinde Bahkesir Turizmi”" başlıklı çalışmanın yazım sürecinde bilimsel, etik ve alıntı kurallarnna uyulmuş; toplanan veriler üzerinde herhangi bir tahrifat yapılmamış ve bu çalışma herhangi başka bir akademik yayın ortamına değerlendirme için gönderilmemiştir. Bu araştırmada doküman incelemesi yapıldığından etik kurul kararı zorunluluğu bulunmamaktadır.

\section{Kaynakça}

Aral, E. (2019). Yeni bir haber mecrası olarak internet gazeteciliği: Facebook ve Twitter kullanımları üzerine bir araştırma. Maltepe Üniversitesi Illetişim Fakültesi Dergisi, 5(2), 153-175.

Arı, Y. (2009). Eko turizm mi ego turizm mi? Kazdağı (Balıkesir) örneği. V. Ulusal Coğraffja Semposyumu (ss. 421-438), Ankara, 16-17 Ekim 2008.

Avraham, E., ve Ketter, E. (2017). Destination image repair while combatting crises: Tourism marketing in Africa. Tourism Geographies, 19(5), 780-800.

Aydın, Ç. ve Aydın, C. (2020). Eskişehir'in turistik destinasyon çekim unsurlarının yerel basındaki sunumu. Erciyes İletisim Dergisi, 7(1), 107-122.

Ayhan, A. ve Kükrer Aydın Ö. (2015). İnternet gazetelerindeki okur yorumlarına yönelik bir analiz (Özgecan Aslan cinayeti örneği). Global Media Journal TR Edition, 6(11), 75-89.

Ayvaz, Ç. (2008). Türkiye'de internet habercilig̈inde fotoğraf (Yüksek Lisans Tezi). Dokuz Eylül Üniversitesi Güzel Sanatlar Enstitüsü, İzmir.

Bal, M. (2011). İmaj ve önyarg1 faktörünün gazete haberlerine etkisi. Kabramanmaraş Sütçü İmam Üniversitesi İktisadi ve İdari Bilimler Fakültesi Dergisi, 1(2), 201-226. 
Balıkesir Büyükşehir Belediyesi Kent Arşivi (2019). Gažteler. http://kentarsivi.balikesir.bel.tr/Gazeteler.aspx. Erişim Tarihi: 22.11.2019.

Balıkesir Kent Portalı (2019). Antik Kentler. https://www.balikesir.com.tr/tr/gezi-rehberi/antik-kentler. Erişim Tarihi: 02.12.2019.

Bargeman, B. ve van der Poel, H. (2006). The role of routines in the vacation decision-making process of Dutch vacationers. Tourism Management, 27(4), 707-720.

Bayram, A.T., Erkol Bayram, G. ve Ak, S. (2018). Gazete internet sayfalarında sağlık turizmi. 19. Ulusal Turizm Kongresi (ss. 824-832), Afyonkarahisar, 18-21 Ekim 2018.

Bayram, Y. (2016). Türk-Arap ilişkileri bağlamında Türk toplumunda değişen Arap imajının turizme yönelik haber çerçevelerinde temsili. Uluslararası Sosyal Araştırmalar Dergisi, 9(43), 1683-1697.

Birsen, H. (2005). İnternet haberciliği ve aktif izlerkitle ilişkisi çerçevesinde etik tartışmalar. Selçuk Üniversitesi İletişim Fakültesi Akademik Dergisi, 3(4), 68-79.

Çakır, H. (2007). Geleneksel gazetecilik karşisinda internet gazeteciliği. Erciyes Üniversitesi Sosyal Bilimler Enstitüsü Dergisi, 1(22), 123-149.

Çelik Uğuz, S. (2011). Sürdürülebilir turizm kapsamında Burhaniye'nin alternatif turizm potansiyeli. Marmara Coğrafya Dergisi, (24), 332-353.

Çetiner, O. ve Çetiner Gökyılmaz, A. (2006). Balıkesir-Ayvalık ilçesi turizmde tanıtma ve pazarlamada yeni yaklaşımkonaklama mekanlarında tasarım etkileri. II. Balkesir Ulusal Turizm Kongresi (ss. 253-264), Balıkesir, 20-22 Nisan 2006.

Çuhadar, E. ve Ünal, F. (2017). Yaşam boyu öğrenmeye katkı sağlayan yerel gazete haberleri (Bartın ili örneği). Journal of International Social Research, 10(49), 416- 423.

Erdoğan, İ. (2006). Türkiye'de ulusal ve yerel gazetelerin habercilik anlayışları: Deprem haberlerinin karşılaştırmalı analizi. Selcuk Üniversitesi İletişim Fakültesi Akademik Dergisi, 4(3), 51-64.

Glesne, C. (2015). Nitel Araştırmaya Giriş (Çev. Edt: A. Ersoy ve P. Yalçınoğlu) (5. Baskı). Ankara: Anı Yayıncılık.

Gül, M. ve Gül, K. (2017). Özel müzelerin kültür turizmi potansiyeli açısından değerlendirilmesi: Balıkesir örneği. Journal of Turkish Tourism Research, 1(4), 52-65.

Güllü, K., Kacur, M. ve Tanyeri, E. (2009). Okuyucuların yerel gazeteleri tercihlerinde etkili olan faktörler ve demografik özellikler itibarı ile algısal farklılıklar. Öneri, 8(32), 271-282.

Gürcan, H. İ. (2005). İnternet haberciliğinde etik değerler. İstanbul Üniversitesi İletişim Fakültesi Dergisi, (22), 39-46.

Gürcan, H. İ. ve Bekiroğlu, O. (2007). Türkiye'de internet gazeteciliği açısından yerel basının genel görünümü ve bölgeler arası bir değerlendirme. Selçk Üniversitesi İletişim Fakültesi Akademik Dergisi, 5(1), 22-29.

Gürdal, M. (2006). Türkiye'de turizmin öncü şehri Balıkesir'e yönelik yeni açılımlar ve firsatlar. II. Bahlkesir Ulusal Turizm Kongresi (ss. 229-244), Balıkesir, 20-22 Nisan 2006.

Güzel, F. Ö. (2012). Kaynak tabanlı turizm kapsamında doğal kaynakların korunmasına yönelik dalyan destinasyonunda örnek olay incelemesi: Caretta Carettalar. Turar Turizm ve Arastırma Dergisi, 1(2), 36-75.

Halıcı, N. (2005). Online gazetecilik. İçinde S. Alankuş (Der.), Yeni iletişim teknolojileri ve medya (ss. 155-170). İstanbul: IPS İletişim Vakfı Yayınları.

İlban, M. O., Köroğlu, A. ve Bozok, D. (2008). Termal turizm amaçlı seyahat eden turistlerde destinasyon imaj1: Gönen örneği. İstanbul Ticaret Üniversitesi Sosyal Bilimler Dergisi, 7(13), 105 -129.

Işık, U. ve Koz, K. A. (2014). Çöp yığınlarında haber aramak: İnternet gazeteciliği üzerine bir çalışma. Humanities Sciences, 9(2), 27-43.

İskender, S. (2005). Karesi gažetesindeki edebî ve kültürel mubteva üzerine bir inceleme (1886-1888) (Yüksek Lisans Tezi). Balıkesir Üniversitesi Sosyal Bilimler Enstitüsü, Balıkesir.

Karaca, K. Ç., Ertürk, N., Köroğlu, Ö. ve Özdemir Yılmaz, G. (2018). Bir kırsal turizm çeşidi olarak astro-turizm ve Balıkesir ilinin astro-turizm potansiyelinin belirlenmesi. Uluslararası Sosyal ve Ekonomik Bilimler Dergisi, 8(2), 1-9.

Karaduman, M. (2005). İnternet ve gazetecilik. İçinde S. Alankuş (Der.), Yeni iletişim teknolojileri ve medya (ss. 141-153). İstanbul: IPS İletişim Vakfi Yayınları.

Kazaz, M. (2007). Geleneksel habercilikten internet haberciliğine geçiş sürecinde spor basını. Selçuk Üniversitesi İletişim Fakültesi Akademik Dergisi, 4(4), 220-229.

Keleşyılmaz, V. (1997). Bir Kuva-yı Milliye gazetesine göre Türk barışı ve İngiltere. Ankara Üniversitesi Türk Inkeılap Taribi Enstitüsü Atatürk Yolu Dergisi, 19, 249-264.

Kervankıran, İ. ve Aktürk, M. (2016). Türkiye'de yazılı medyanın turizme yaklaşımı: Sorun çok, ilgi yok. Journal of Recreation and Tourism Research, 3(2), 36-49.

Kervankıran, İ., Çuhadar, M. ve Ongun, U. (2020). Turizm araştırmalarında ihmal edilen bir konu: Turist ölümleri (Antalya örneği). International Journal of Geography and Geography Education, (42), 155-167.

Kocabaşoğlu, U. ve Birinci, A. (1995). Osmanlı vilâyet gazete ve matbaaları üzerine gözlemler. Kebikeȩ, 2, 101-122.

Korkmaz, A. (2009). İnternet gazeteciliğinin kamuoyu oluşumuna etkisi. Erciyes İletisim Dergisi, 1(2), 6-19.

Kutlu, T. Ö. ve Bekiroğlu, O. (2010). Türkiye'de yurttaş gazeteciliği bağlamında internet haberciliği: Bianet örneğinde kentsel dönüşüm projesiyle ilgili haberlerin analizi. Selçu Üniversitesi İletişim Fakültesi Akademik Dergisi, 6(2), 254269. 
Mayaka, M. A., ve Prasad, H. (2012). Tourism in Kenya: An analysis of strategic issues and challenges. Tourism Management Perspectives, 1, 48-56.

Narin, F. B. (2016). İnternet gazeteciliğinde hipermetin üretimi. İetişim Kuram ve Araştırma Dergisi, (43), 119-149.

Özdemir Yılmaz, G. ve Kafa Gürol, N. (2012). Balıkesir ilinin kirsal turizm potansiyelinin değerlendirilmesi. Karamanoğlu Mehmetbey Üniversitesi Sosyal ve Ekonomik. Araștırmalar Dergisi, 14(23), 23-32.

Özdemir, M. ve İlhan, E. (2012). Geleneksel ve internet gazeteciliği’nde haber ve fotoğraf kullanımı: Milliyet örneği. Batman Üniversitesi Yaşam Bilimleri Dergisi, 1(1), 807-816.

Öztürk, F., Zülkadiroğlu, Z., İnce, G. ve Şahin, M. (1999). Yerel günlük gazetelerde sporun yer alışı. CBÜ Beden Eğitimi ve Spor Bilimleri Dergisi, 3(2), 1-10.

Öztürk, Ș. (2018). Gazetecilik 2.0 internet gazeteciliğinde hipermetinsellik. Üsküdar Üniversitesi İletişim Fakültesi Akademik Dergisi Etkilesim, (2), 198-201.

Polat, E. (2017). Turizm ve coğrafi işaretleme: Balikesir örneği. Meriç Uluslararası Sosyal ve Stratejik Araștırmalar Dergisi, 1(1), 17-31.

Polat, E., Özdemir, S. S. ve Özdemir, M. (2014). Kırsal turizm potansiyelinin swot analizi ile değerlendirilmesi: Balıkesir örneği. Coğrafyacılar Derneği Uluslararası Kongresi (ss. 143-153), Muğla, 4-6 Haziran 2014.

Polat, N. H. (2002). Türkiye'de yerel basının gelișimine kısa bir bakıș. Türklük Bilimi Araștırmalar, (12), 7-25.

Reichart, I. ve Hischier, R. (2001). Environmental impact of electronic and print media: Television, Internet newspaper and printed daily newspaper. In Sustainability in the Information Society, 15th International Symposium on Informatics for Environmental Protection (ss. 91-98), Metropolis Verlag.

Şahan, H. ve Çınar, V. (2004). Kitle iletişim araçlarının spor kamuoyu üzerine etkisi. Selçuk Üniversitesi Sosyal Bilimler Enstitüsü Dergisi, (12), 313-321.

Şeker, M. (2005). Yerel gazeteler ve resmi ilan. Selçk Üniversitesi İletişim Fakültesi Akademik Dergisi, 4(1), 101-115.

Sezen Doğancilı, O. (2019). Türkiye'ye gelen yabancı turistlerin ölümlerine ilişkin gazete haberlerinin incelenmesi üzerine çalışma. Uluslararası Sosyal Araştırmalar Dergisi, 12(62), 1567-1573.

Şimşek, E. ve Hassan, A. (2018). The Independent ve The Guardian gazeteleri internet sitelerinde yer alan Türkiye turizm yazılarına yönelik bir içerik analizi. Gaži Üniversitesi Turižm Fakültesi Dergisi, (1), 80-103.

Soykan, A., Efe, R., Sönmez, S. ve Cürebal, İ. (2008). Balıkesir ili’nin mağara turizmi potansiyeli. 3. Ulusal Balıkesir Turizm Kongresi (ss. 393-400), Balıkesir, 17-19 Nisan 2008.

Stepchenkova, S., ve Eales, J. S. (2011). Destination image as quantified media messages: The effect of news on tourism demand. Journal of Travel Research, 50(2), 198-212.

T.C. Balıkesir Valiliği (2017). Misya yürüyüss yollar Balkesir. İstanbul: Deva Matbaacılık ve Reklam Hizmetleri San. Tic. Ltd. Ști.

T.C. Kültür ve Turizm Bakanlığ1 Balıkesir İl Kültür ve Turizm Müdürlügü (2019a). Turizm potansiyelimiz. https://balikesir.ktb.gov.tr/TR-90620/turizm-potansiyelimiz.html. Erişim Tarihi: 25.11.2019.

T.C. Kültür ve Turizm Bakanlığ1 Balıkesir İ Kültür ve Turizm Müdürlüğü (2019b). Müzeler. https://balikesir.ktb.gov.tr/TR-90611/muzeler.html. Erişim Tarihi: 27.11.2019.

T.C. Orman ve Su İşleri Bakanlığ1 Doğa Koruma ve Milli Parklar Genel Müdürlüğü 3. Bölge Müdürlüğü Balıkesir Şube Müdürlüğü (2012). Bahkesir Doğa Turizmi Master Plam 2013-2023.

T.C. Sanayi ve Teknoloji Bakanlı̆̆ı, Türk Patent ve Marka Kurumu (2019). Coğrafi işaret ve geleneksel ürün adı istatistikleri. https://www.turkpatent.gov.tr/TURKPATENT /geographicalRegisteredList/. Erişim Tarihi: 27.11.2019.

Tuncel, I. (2011). Turizmin cinsiyeti ya da kadın gölgesinde turizm. Gümüşane Üniversitesi İletişim Fakültesi Elektronike Dergisi, (2), 140-164.

Ulusoy Yıldırım, H., Köroğlu, Ö., Avcıkurt, C. ve Köroğlu, A. (2018). Balıkesir ilindeki turizm faaliyetlerinin değerlendirilmesine yönelik swot analizi. Uluslararası Necatibey Eğitim ve Sosyal Bilimler Araştırmalar Kongresi (ss. 217-235), Balıkesir, 26-28 Ekim 2018.

Yazıc1, N. (1993). Hasan Basri (Çantay) ve Ses Gazetesi. Ankara Üniversitesi Türk Inkılap Taribi Enstitüsü Atatürk Yolu Dergisi, 3(12), 431-445.

Yegen, C. (2014). İnternet haberciliğinde kadın cinayeti haberlerinin sunumu: Posta Gazetesi örneği. The Turkish Online Journal of Design, Art and Communication - TOJD AC, 4(3), 15-28.

Yeşil, M. M. (2015). Üniversite öğrencilerinin yerel gazete okuma alışkanlıkları: Konya örneği. Selçuk İletisim, 9(1), 201-222.

Yıldırım, A. ve Karaahmet, A. (2013). Yavaş şehir hareketinin kent imajına katkısı: Ordu-Perşembe örneğinin yerel basin üzerinden analizi. Sosyal ve Beşeri Bilimler Dergisi, 5(1), 11-20.

Yıldırım, A. ve Şimşek, H. (2013). Sosyal bilimlerde nitel araştırma yöntemleri (Genişletilmiş 9. Baskı). Ankara: Seçkin.

Yıldırım, A. ve Şimşek, H. (2016). Sosyal bilimlerde nitel araştırma yöntemleri (Genişletilmiş 10. Baskı). Ankara: Seçkin.

Yılmaz, H. ve Çakıcı, H. H. (2019). Yazılı medyada Türk mutfağı. Journal of Tourism and Gastronomy Studies, 7(1), 450462.

Yılmaz, M. ve Parlak, A. B. (2017). Trabzon'da turizm farkındalığının yerel basın üzerinden incelenmesi. DOKAP Bölgesi Uluslararası Turizm Sempozyumu (ss. 109-121), Trabzon, 23-24 Ekim 2017.

Yurdigül, Y. ve Zinderen, İ. E. (2012). Yeni medyada haber dili (Ayşe Paşalı olayı üzerinden geleneksel medya ve internet haberciliği karşılaştırmas1). The Turkish Online Journal of Design Art and Communication, 2(3), 81-91. 
Yücedoğan, G. (2002). İnternet haberciliği. İstanbul Üniversitesi İletişim Fakültesi Dergisi, (14), 143-150.

\section{EXTENDED ABSTRACT}

Newspaper news inform readers about the destination whereas local newspapers function to reflect the destination. It can also provide benefits in terms of tourism when used correctly and adequately. In this manner, local newspapers are one of the most useful news tools to acquire news and knowledge about a region from a local perspective. Today, local newspapers, which are getting stronger with the internet, have had the chance to reach a wider audience and have had the opportunity to convey the news on many different topics to more readers. Ballkesir, where tourism movement began in Turkey, has quite strong potential in terms of alternative tourism types. In addition to its rich fauna and flora, various tourism types such as cultural tourism, diving tourism, endemic plant species, water skis, eco-tourism, ornithology tourism, sea tourism and thermal tourism come to the fore. In addition, important tourism attractions such as Ayvalık, Edremit Kazdağları National Park, Kapıdağ Peninsula and Manyas "Kuş Cenneti" National Park are located within the city borders (Balıkesir Provincial Directorate of Culture and Tourism, 2019). Nevertheless, no study evaluating local newspaper news about Balıkesir tourism has been come across. For this reason, it is thought that the results will contribute to the relevant literature since the study specially addresses Balıkesir tourism. In this respect, the aim of this research is to find out how Balıkesir takes place in the Internet news in terms of tourism. In accordance with this purpose, questions related to the frequency of news by districts, newspapers and months, the prominent themes, and the distribution by districts were searched. A document analysis was conducted applying qualitative research method. Thematic analysis, which is one of the qualitative research methods, was preferred to obtain themes and codes in order to examine the data in depth. In the retrospective analysis, the news was examined in terms of content and quantitative aspects. Local newspapers under the title of Balikesir on the official website of the Press Advertisement Agency were scanned. 26 local newspapers were identified and examined, 19 newspapers containing tourism news were evaluated. "Balıkesir" and "Tourism" (in Turkish) keywords were searched on the local newspaper web pages. The data collection process was limited to the first eight months of the year between January 2019 and August 2019. Therefore, the data obtained with this restriction sheds light on the developments and changes towards Ballkesir tourism in the first eight months of 2019. In line with the news, different themes were created, but among them, numerically and in terms of diversity, themes related to activity, tourism potential and environment works came to the forward. Especially the theme of the event was used very often. That's why this result can be considered as evidence of the importance of the activities in the promotion of the destination, and the use of activities as a promotional element. The fact that tourism diversity is generally reflected in the news in Balikesir supports the fact that Balıkesir has tourism potential in all seasons. However, interestingly, the least used themes are marketing and protection. This is an alarming situation for the future of Balikesir tourism since these themes are critical factors that improve tourism appeal of a destination, make it easier for tourists to make decisions, and direct them to the destination. Considering the news examined, another astonishing result is that the tourism news prepared in similar manner. Sometimes the same news is presented with the same sentences. As a result, when looking at Balikesir from the perspective of local newspapers; it is seen that Balikesir is a province that hosts different types of tourism, has a high number of activities, has a high tourism potential, but has insufficiencies in infrastructure and is on the way to branding. In this context, some suggestions have been presented. First, while the news is being analyzed, news with similar content is frequently encountered. For this reason, there was a lack of local news content uniqueness. In some newspapers, no result was encountered when the keyword "tourism" was searched. In this regard, journalists have important duties. In addition, as news related to investments it can support regional tourism, it has been deemed necessary to include more news of upcoming investments or investment supports. It is also thought that increasing the number of criticism and column articles, or destination-related comments and recommendations can be both guiding and promoting for local administrations and potential visitors. Lastly, in future studies, it may be beneficial to understand the views or perceptions of journalists by making interviews with them. In addition, the keyword "tourism" can be searched in national newspapers by expanding the date range. 